\title{
Common features and interesting differences in transcriptional responses to secretion stress in the fungi Trichoderma reesei and Saccharomyces cerevisiae
}

\author{
Mikko Arvas*1, Tiina Pakula1, Karin Lanthaler², Markku Saloheimo1, \\ Mari Valkonen ${ }^{1}$, Tapani Suortti ${ }^{1}$, Geoff Robson ${ }^{2}$ and Merja Penttilä ${ }^{1}$
}

Address: ${ }^{V}$ VTT Biotechnology, Tietotie 2, Espoo, PL 1500, 02044 VTT, Finland and ${ }^{2}$ School of Biological Sciences, University of Manchester, 1800 Stopford Building, Oxford Road, Manchester M13 9 PT, UK

Email: Mikko Arvas* - mikko.arvas@vtt.fi; Tiina Pakula - tiina.pakula@vtt.fi; Karin Lanthaler - karin.lanthaler@man.ac.uk; Markku Saloheimo - markku.saloheimo@vtt.fi; Mari Valkonen - mari.valkonen@vtt.fi; Tapani Suortti - tapani.suortti@vtt.fi; Geoff Robson - geoff.robson@man.ac.uk; Merja Penttilä - merja.penttila@vtt.fi

* Corresponding author

Published: 22 February 2006

BMC Genomics 2006, 7:32 doi:10.1 186/147|-2164-7-32
Received: 03 November 2005

Accepted: 22 February 2006

This article is available from: http://www.biomedcentral.com/I47I-2/64/7/32

(c) 2006 Arvas et al; licensee BioMed Central Ltd.

This is an Open Access article distributed under the terms of the Creative Commons Attribution License (http://creativecommons.org/licenses/by/2.0), which permits unrestricted use, distribution, and reproduction in any medium, provided the original work is properly cited.

\begin{abstract}
Background: Secretion stress is caused by compromised folding, modification or transport of proteins in the secretory pathway. In fungi, induction of genes in response to secretion stress is mediated mainly by the unfolded protein response (UPR) pathway. This study aims at uncovering transcriptional responses occurring in the filamentous fungi Trichoderma reesei exposed to secretion stress and comparing these to those found in the yeast Saccharomyces cerevisiae.

Results: Chemostat cultures of $T$. reesei expressing human tissue plasminogen activator (tPA) and batch bioreactor cultures treated with dithiothreitol (DTT) to prevent correct protein folding were analysed with cDNA subtraction and cDNA-amplified fragment length polymorphism (AFLP) experiments. ESTs corresponding to 457 unique genes putatively induced under secretion stress were isolated and the expression pattern of 60 genes was confirmed by Northern analysis. Expression of these genes was also studied in a strain over-expressing inositol-requiring enzyme I (IREI) protein, a sensor for the UPR pathway. To compare the data with that of $S$. cerevisiae, published transcriptome profiling data on various stress responses in $S$. cerevisiae was reanalysed. The genes up-regulated in response to secretion stress included a large number of secretion related genes in both organisms. In addition, analysis of $T$. reesei revealed up regulation of the $c p c I$ transcription factor gene and nucleosomal genes. The induction of the cpcA and histone gene $\mathrm{H} 4$ were shown to be induced also in cultures of Aspergillus nidulans treated with DTT.
\end{abstract}

Conclusion: Analysis of the genes induced under secretion stress has revealed novel features in the stress response in T. reesei and in filamentous fungi. We have demonstrated that in addition to the previously rather well characterised induction of genes for many ER proteins or secretion related proteins also other types of responses exist. 


\section{Background}

In eukaryotic cells after translocation to the endoplasmic reticulum (ER), the folding of secreted proteins is supported and controlled by chaperones, glycosylation enzymes and oxidoreductases. The correctly folded proteins are transported to the Golgi compartment where further modification of the proteins takes place and the proteins are thereafter secreted out of the cell. Accumulation of unfolded, misfolded or otherwise inefficiently secreted proteins or other impairing of secretion can cause stress to cells, i.e. secretion stress. Secretion stress can be induced by heterologous proteins, leading to reduced yields of proteins or by exposure of cells to various chemicals that inhibit protein folding or transport and induce strong, clearly measurable responses.

Eukaryotic cells respond in various ways to secretion stress. The best known response is the unfolded protein response (UPR) which is thought to modify and enhance the activity of the secretion pathway. In fungi, it is defined mainly through its transcriptional effects that are controlled by the sensor Ire1p and the downstream transcription factor Hac1p, as first described in S. cerevisiae. Ire1p splices HAC1 mRNA and only then Hac1p is actively translated and capable of activating its downstream genes [1]. The induction of almost 400 genes has been shown to depend on the IRE1 and HAC1 pathway [2]. Recently it has been shown that the transcription factor Gen $4 p$ is also required for induction of majority of these genes [3].

The response to secretion stress in $T$. reesei has previously been shown to share several features in common with $S$. cerevisiae. Components of the UPR pathway have been isolated from $T$. reese $i$ including the counterparts of the genes IRE1 and HAC1, as well as UPR target genes such as PDI1. In T. reesei and Aspergillus niger splicing of hac1/hacA mRNA and HAC1/HACA promoter binding activity has been shown [4-6]. T. reesei and A. niger exhibit also transcriptional down regulation of genes encoding secreted proteins (REpression under Secretion Stress, RESS) $[7,8]$ which has not been described in S. cerevisiae, but which is likely to be functional in Arabidopsis thaliana [9]. Whether this response is directly dependent on UPR is currently not known.

In mammalian cells the UPR genes are regulated mainly by the actions of IRE $1 \alpha$ and ATF 6 which activate the XBP1 transcription factor that induces the UPR genes [10]. In addition, a PKR-like ER kinase (PERK) is activated by unfolded proteins in the ER and it phosphorylates the $\alpha$ subunit of the translation initiation factor 2 (eIF2 $\alpha$ ) [11]. Phosphorylation of eIF2 $\alpha$ leads to attenuation of general translation initiation, but also to a concomitant translational activation of selected proteins, including ATF4 [12], a homologue of S. cerevisiae Gcn4p. ATF4 is similarly acti- vated by GCN2 during amino acid deprivation. However the ATF4 mediated responses to secretion stress and amino acid deprivation appear to be distinct [12-14]. In secretion stress ATF4 transcriptionally up-regulates genes in amino acid biosynthesis related functions apparently to relieve oxidative stress caused by protein secretion stress [13].

T. reesei secretes large amounts of extracellular enzymes such as cellulase, which may set special demands for the capacity of its cells to fold and transport proteins. In agreement with this, the induction of cellulase production in $T$. reesei has been shown to coincide with UPR induction $[15,16]$. In this study we have set out to characterise further the transcriptional responses of $T$. reesei during secretion stress. Due to the lack of genome data when the work was initiated, we used cDNA-subtraction and cDNA-AFLP methods in the analysis. Responses to production of a heterologous protein and to treatment with the chemical agent DTT were studied. Expression of the genes was analyzed also in a transformant over-expressing the ire 1 gene and displaying constitutive UPR induction. The genome sequence of $S$. cerevisiae has for long been available to the research community and the pathways for protein transport and UPR signalling are well characterised. We combined transcriptome data from publications where various treatments causing secretion stress in S. cerevisiae had been studied and reanalysed it to define groups of genes upregulated or downregulated, either in UPR dependent or independent manner. We provide, for the first time, such complete lists of gene groups for the research community. We compared these gene groups to the secretion stress induced genes detected by us in $T$. reesei. We discovered up regulation of the $c p c 1 /$ gnc4/ATF4 homologue of $T$. reesei in accordance with studies made with mammals and $S$. cerevisiae. Interestingly also two nucleosome genes are up-regulated uniquely in $T$. reese $i$ without a clear connection to cell cycle. The induction of the cpcA and histone gene $\mathrm{H} 4$ were shown to be induced also in cultures of $A$. nidulans treated with DTT.

\section{Results \\ Computational reanalysis of S. cerevisiae transcriptome data from secretion stress causing conditions}

To better understand our transcriptome data on the responses to secretion stress in T. reesei, it was essential to evaluate the specificity of the responses to the type of stress imposed and to identify responses specific to T. reesei in particular. To enable reliable comparison we first combined the published data on the transcriptional responses to secretion stress related conditions in S. cerevisiae and analysed the data further. These were from $S$. cerevisiae cultures treated with DTT or tunicamycin to inhibit protein folding and transport [2,3,17-19], and cultures of $S$. cerevisiae producing a secreted mouse histocom- 

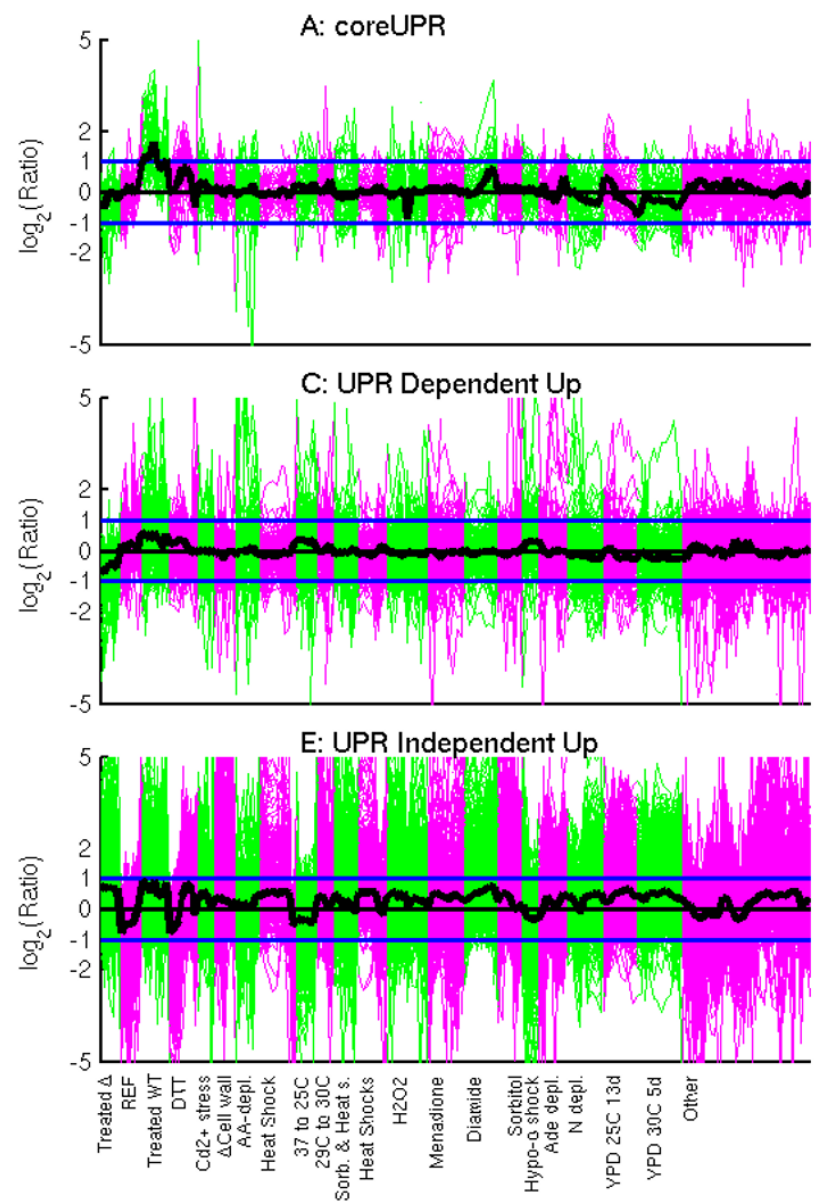
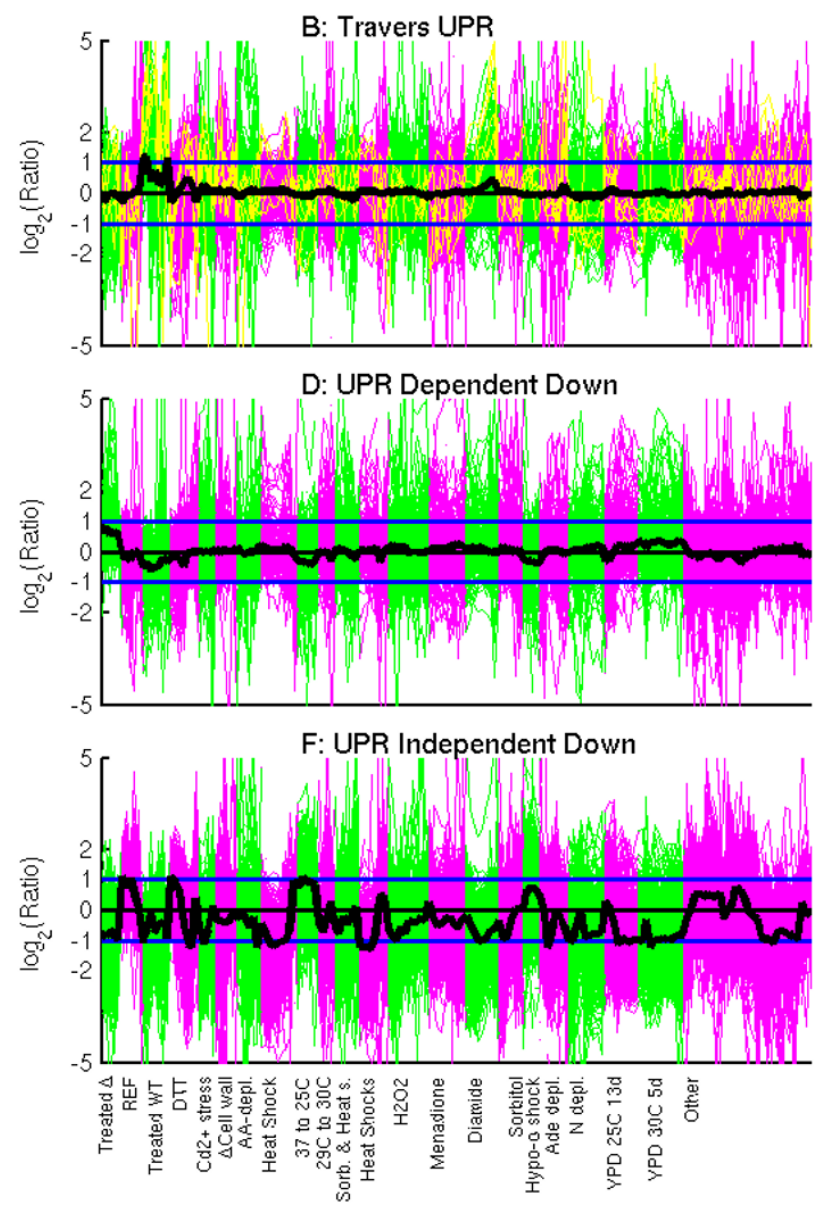

Figure I

Expression of secretion stress related genes of S. cerevisiae under different stress conditions. Expression values of the genes (shown as $\log _{2}$ of the expression level ratio in stress vs. reference conditions) from I74 different stress conditions were collected from published articles. The expression level values of individual genes are shown in purpleor greenand the median of the gene group in blackand the standard deviation of the whole experiment in blue. A: "coreUPR", genes showing significant up regulation in "Treated WT" experiment set against both the "Treated $\rho$ " and "REF" experiment sets. B: "Travers UPR", genes defined as UPR genes and genes defined as UPR model genes in yellowby [2]. C: "UPR Dependent UP", genes showing significant up regulation only in "Treated WT" set against "Treated $\rho$ " set. D: "UPR Dependent Down", genes showing significant down regulation only in "Treated WT" against "Treated $\rho$ " set. E: "UPR Independent UP", genes showing significant up regulation only in "Treated WT" against "REF" set. F: "UPR Independent Down", genes showing significant down regulation only in "Treated WT" against "REF" set. The stress conditions were divided in sets as follows:

Treated $\rho$ IREI and HACI deletion strains treated with DTT or tunicamycin, used as UPR dependent reference set in this study [2, 3]; REF reference set, used as UPR independent reference in this study [17, 18]; Treated WT cultures treated with DTT or tunicamycin or recombinant strains producing a secreted heterologous protein, used as UPR conditions in this study [2, 3, 17-19, 69]; DTT DTT treatment, $4 \mathrm{~h}$ time series [17]; Cd2+ stress $\mathrm{Cd}^{2+}$ treatment, $2 \mathrm{~h}$ time series and met4 deletion [48]; $\rho$ Cell Wall strains deleted in cell wall genes [49]; AA-depl. methyl methanesulfonate, 3-aminotriazole and amino acid depletion treatments and GCN4 constitutive and GCN4 deletion strains [35]; Heat Shock I h time series after heat shock from $25^{\circ} \mathrm{C}$ to $37^{\circ} \mathrm{C}$, [ I7]; 37 to $25 \mathrm{I}, 5 \mathrm{~h}$ time series after temperature shift from $37^{\circ} \mathrm{C}$ to $25^{\circ} \mathrm{C}$, [I7]; 29C to $33 \mathrm{C} \mathrm{I}, 5 \mathrm{~h}$ time series after mild heat shock of $29^{\circ} \mathrm{C}$ to $33^{\circ} \mathrm{C}$ [ I7]; Sorbi. \& Heat S. mild heat shock with different osmolarities, like previous but with sorbitol treatments [ I7]; Heat Shocks different heat shocks [ I7]; H202 2 h time series after hydrogen peroxide treatment [ 17]; Menadione $2 \mathrm{~h}$ time series after menadione treatment [ 17]; Diamide I, $5 \mathrm{~h}$ time series after diamide treatment [ I7]; Sorbitol $2 \mathrm{~h}$ time series after hyper-osmotic shock with sorbitol [17]; Hypo-o shock I h time series after hypoosmotic shock with sorbitol [17]; Ade. depl. $6 \mathrm{~h}$ time series after amino acid and adenine depletion [I7]; $\mathbf{N}$ depl. $3 \mathrm{~d}$ time series after nitrogen depletion [I7]; YPD $25 \mathrm{C} \mathrm{I3} \mathrm{d} \mathrm{I3} \mathrm{d} \mathrm{time} \mathrm{series} \mathrm{of} \mathrm{growth} \mathrm{on} \mathrm{YPD} \mathrm{at} 25^{\circ} \mathrm{C}$ [I7]; YPD $30 \mathrm{C} 5$ d $5 \mathrm{~d}$ time series of growth on YPD at $30^{\circ} \mathrm{C}$ [17]; Other other conditions [17]. 
Table I: Representation of different function and location categories of genes in the different groups of secretion stress related genes of $S$. cerevisiae. Number of $S$. cerevisiae genes belonging to selected function and location categories within the different groups of secretion stress related genes distinguished in this article. The groups of differentially regulated genes: "coreUPR", "UPR Dependent Up "UPR Dependent Down", UPR Independent Up" and "UPR Independent Down", are defined in Materials and methods of this study and "UPR by Travers \& al. 2000" (UPR regulated genes) are as described by [2], and "Homologues of T. reesei secretion stress ORFs" (numbers of ORFs corresponding to ESTs represented in the CDNA subtraction library and cDNA-AFLP analysis in this study). Category assignments are from CYGD functional or localization categories [5 I].

\begin{tabular}{|c|c|c|c|c|c|c|c|c|c|}
\hline Topic & Category & CUPR & $\begin{array}{c}\text { UPR } \\
\text { Dependent } \\
\text { UP }\end{array}$ & $\begin{array}{c}\text { UPR } \\
\text { Dependent } \\
\text { DOWN }\end{array}$ & $\begin{array}{l}\text { Not UPR } \\
\text { Dependent } \\
\text { UP }\end{array}$ & $\begin{array}{l}\text { Not UPR } \\
\text { Dependent } \\
\text { DOWN }\end{array}$ & $\begin{array}{l}\text { UPR by } \\
\text { Travers \& } \\
\text { al. } 2000\end{array}$ & $\begin{array}{c}\text { Homologues } \\
\text { of T. reesei ER } \\
\text { stress ORFs }\end{array}$ & $\begin{array}{l}\text { S. cerevisiae } \\
\text { genome }\end{array}$ \\
\hline \multirow{7}{*}{$\begin{array}{l}\text { Protein } \\
\text { secretion } \\
\text { related }\end{array}$} & $\begin{array}{l}\text { Cellular export and } \\
\text { secretion }\end{array}$ & & & 2 & II & 3 & 3 & 7 & 76 \\
\hline & Protein fate & 23 & 30 & 25 & 137 & 65 & 95 & 62 & 1130 \\
\hline & $\begin{array}{l}\text { Lipid, fattyacid and } \\
\text { isoprenoid } \\
\text { metabolism }\end{array}$ & 6 & 10 & 5 & 33 & 18 & 28 & 16 & 271 \\
\hline & Vacuolar transport & 2 & 2 & 4 & 26 & 9 & 10 & 11 & 152 \\
\hline & Vesicular transport & 8 & 5 & 3 & 23 & 7 & 27 & 20 & 197 \\
\hline & $\begin{array}{l}\text { Biogenesis of cellular } \\
\text { componentsCell wall }\end{array}$ & 2 & 8 & 4 & 21 & 11 & 21 & 16 & 212 \\
\hline & $\begin{array}{l}\% \text { of Protein } \\
\text { secretion related } \\
\text { genes in the group }\end{array}$ & $63 \%$ & $31 \%$ & $20 \%$ & $34 \%$ & $16 \%$ & $38 \%$ & $39 \%$ & $26 \%$ \\
\hline \multirow[t]{3}{*}{$\begin{array}{l}\text { Transcription } \\
\text { related }\end{array}$} & $\begin{array}{l}\text { Transcriptional } \\
\text { control }\end{array}$ & 1 & 23 & 8 & 44 & 33 & 26 & 23 & 491 \\
\hline & Transcription & 3 & 35 & 19 & 69 & 140 & 48 & 31 & 1060 \\
\hline & $\begin{array}{l}\% \text { of Transcription } \\
\text { related genes in } \\
\text { the group }\end{array}$ & $7 \%$ & $26 \%$ & $13 \%$ & $12 \%$ & $23 \%$ & $13 \%$ & $14 \%$ & $17 \%$ \\
\hline \multirow[t]{5}{*}{ Outside of cell } & Extracellular & & & I & 2 & 9 & 5 & 5 & 50 \\
\hline & Cellwall & & & & 2 & 5 & I & 3 & 40 \\
\hline & $\begin{array}{l}\% \text { of genes } \\
\text { Outside of cell in } \\
\text { the group }\end{array}$ & $0 \%$ & $0 \%$ & $1 \%$ & $1 \%$ & $2 \%$ & $1 \%$ & $2 \%$ & $1 \%$ \\
\hline & Ribosome biogenesis & & 2 & 3 & & 130 & 3 & 20 & 301 \\
\hline & Histones & & & & & & & 3 & 8 \\
\hline \multirow{2}{*}{\multicolumn{2}{|c|}{$\%$ of Unclassifed genes in the group }} & $20 \%$ & $21 \%$ & $40 \%$ & $27 \%$ & $17 \%$ & $27 \%$ & $9 \%$ & $32 \%$ \\
\hline & & 46 & 135 & 155 & 592 & 603 & 381 & 249 & 6335 \\
\hline
\end{tabular}

patibility protein [19] (selected for the experiment set "Treated WT", Fig. 1). In order to analyse whether the observed transcriptional responses were dependent on the UPR pathway genes HAC1 and IRE1, the data sets were compared to the data from DTT and tunicamycin treatment of cultures of IRE1 and HAC1 deletion strains [2,3] (experiment set "Treated $\Delta$ ", Fig. 1). In this analysis we used as reference data not yet induced early time points of DTT and heat shock time series experiments from [17] as well as two randomly picked reference cultures from [18] (experiment set "REF", Fig. 1). Genes showing significant differences in the expression between the secretion stress and reference cultures were selected using ranksum test, and the genes were divided into groups based on their expression pattern. Briefly, for each gene we tested if there was a significant difference between expression values in experiment sets "Treated WT" and "REF" and/or a significant difference between expression values in experiment sets "Treated $\Delta$ " and "Treated WT". The genes whose expression was up-regulated significantly by secretion stress (difference between "Treated WT" and "REF") and for which this change was significantly dependent of IRE1 and HAC1 (difference between "Treated $\Delta$ " and "Treated WT") were assigned to "coreUPR" (cUPR). Those genes which were only significantly dependent of IRE1 and HAC1 (difference between "Treated $\Delta$ " and "Treated WT", but no significant difference "Treated WT" and "REF"), thus showing less change, were divided by comparing the median gene expression values of experiment sets into "UPR Dependent Up" and "UPR Dependent Down". Respectively, genes which only changed significantly by secretion stress (difference between "Treated WT" and "REF"), were divided into "UPR Independent Up" and "UPR Independent Down". A detailed list of the genes in the groups is included as supplemental data. The expression of the genes in the different groups was also compared in other type of stress conditions in S. cerevisiae, including published data from 174 conditions. The data is 
summarised in Fig. 1. For comparison also the expression of the genes in the set described to be up regulated under UPR conditions IRE1 and HAC1 dependently by [2] is included.

The group of genes designated as "coreUPR" contained 46 genes up regulated significantly and UPR dependently under the secretion stress (Fig. 1A). The behaviour of this group is exceptional among the six gene groups shown in Fig. 1. It shows the least responses in the other stress conditions as the expression values of individual genes are mostly contained within the 2 -fold limit $\left(-1,1\right.$ on the $\log _{2}$ scale plot). Interestingly it responds slightly to diamide treatment in data of [17], like the UPR gene set described by [2].

In addition to the "coreUPR" genes, a group of 135 genes showed significant dependence on UPR and were up regulated ("UPR Dependent UP", Fig. 1C). However they are not as strongly UPR-regulated, as they have no significant difference between gene expression values of experiment sets "Treated WT" and "REF". 155 genes showed UPR dependence and were down regulated ("UPR Dependent Down", Fig. 1D). Some of the genes in the groups "UPR Dependent Up" and "UPR Dependent Down" genes showed responses also in other stress conditions. In many cases the responses of the up regulated and down regulated genes were characterised by slightly opposite behaviour also in other stress conditions. For example, the median of the group of "UPR Dependent Up" genes was slightly higher also in the hypo-osmotic shock conditions whereas the median of the "UPR Dependent Down" genes was lower in these conditions.

592 genes were assigned to groups "UPR Independent Up" and 603 "UPR Independent Down". These gene groups (Fig 1E, F), in contrast to UPR dependent gene groups, were effected also by many other types of stress. For example 105 of "UPR Dependent Up" and 305 of "UPR Dependent Down" group members are environmental stress genes, a form of general stress response defined by [17]. Genes assigned to groups 2, 7 and 8, described, provided and plotted in supplemental data, were judged to be outside the scope of this publication.

The content of the gene groups was compared also based on the number of genes in different function and location categories (Table 1). All gene groups up-regulated under secretion stress contained a higher percentage of secretion related genes compared to the total of the genome content of $S$. cerevisiae, whereas the down regulated gene groups showed a lower percentage of secretion related genes compared to the genome content (Table 1). Especially in the "coreUPR" group the secretion related genes were overrepresented, $63 \%$ of the genes vs. $26 \%$ of the genes in the whole genome. The second most prominent category was the genes related to transcription. In the gene group "UPR Dependent Up" the percentage of transcription related genes is well above their total amount in the genome, $26 \%$ vs. $17 \%$. It is of interest that there is little evidence for down regulation of genes encoding secreted proteins in $S$. cerevisiae transcriptome data in secretion stress conditions (Table 1). In total, ten transcripts encoding proteins localised outside the cell showed down regulation independently of UPR, but this is only $15 \%$ of the genes encoding extracellular proteins in S. cerevisiae and the possible targets for the RESS phenomenon described in filamentous fungi $[7,8]$.

\section{EST collection derived from CDNA-AFLP and CDNA subtraction library analysis of $\mathrm{T}$. reesei cultures under secretion stress conditions}

In order to identify genes that are differentially expressed in response to secretion stress in $T$. reesei, we prepared cDNA subtraction libraries from chemostat cultures of a tPA producing transformant of $T$. reesei Rut-C30 and its parental strain and from a batch bioreactor culture of $T$. reesei Rut-C30 treated with DTT and an untreated reference culture. In addition, the same cultures were subjected to CDNA-AFLP analysis to gather additional information using another method.

In preparation of the subtraction libraries, the sample and reference libraries were hybridised repeatedly to enrich fragments that are more abundant in the sample library. Progress of hybridisations was monitored by hybridising DNA probes such as bip1 and pdi1 gene fragments to dotplots of libraries and measuring the amount cDNA removed from libraries in each hybridisation cycle by radioactivity. Even after one round of hybridisation a clear selective enrichement of bip1 and pdi1 mRNA could be seen. In each hybridisation round some cDNA was removed indicating removal of non-regulated genes (data not shown). To cover broadly the produced libraries, four of those were selected for further analysis: libraries representing the culture treated with DTT for 60 min after 1 and 5 hybridisation cycles and libraries representing the tPA producing culture after 1 and 5 hybridisation cycles. In the cDNA-AFLP experiment the sample and reference cDNAs are amplified by a PCR based protocol and fractionated using electrophoresis. Bands that showed very clear up regulation in both (tPA and DTT $60 \mathrm{~min}$ ) stressed samples were

sequenced.

In total 2144 individual EST sequences were retrieved, including 94 fragments obtained from the cDNA-AFLP analysis. The ORFs corresponding to the ESTs were identified based on sequence similarity searches against the prepublication version of the $T$. reesei genome and the predicted $T$. reesei proteome, and subsequently the puta- 
Table 2: The most abundant ORFs in the secretion stress related ESTs of T. reesei. 25 ORFs represented by the highest number of ESTs in the cDNA subtraction libraries or CDNA-AFLP fragments derived from the secretion stress conditions are listed. Gene names from $T$. reesei (small case letters) or S. cerevisiae (capital letters) are shown. Description and T. reesei protein model identifiers (ID) are from T. reesei genome version I.2 website. The number of ESTs corresponding to the genes in the libraries are shown: "AFLP", fragments from cDNA-AFLP analysis induced in both tPA expression and DTT treatment; "DTThyb I", subtraction library from DTT treated culture after one subtraction round; "DTTHyb5", subtraction library from DTT treated culture after five subtraction rounds; "tPAhyb I", subtraction library from the tPA producing culture after one subtraction round; "tPAHyb5", subtraction library from tPA producing culture after five subtraction rounds.

\begin{tabular}{|c|c|c|c|c|c|c|c|c|}
\hline Gene & $\begin{array}{l}T . \text { reesei } \\
\text { protein } \\
\text { Model ID }\end{array}$ & Description & AFLP & DTThybl & DTThyb5 & tPAhybl & tPAhyb5 & Total \\
\hline TEF2 & tre4I793 & translational elongation & & 25 & 12 & 42 & 18 & 97 \\
\hline \multirow[t]{2}{*}{ bipl } & tre42955 & HSP70 family ER chaperone & 1 & 55 & I & I & & 58 \\
\hline & tre42349 & posttranslational modification, protein turnover & & 40 & 15 & 1 & 2 & 58 \\
\hline UBI4 & tre45056 & posttranslational modification, protein turnover & & 46 & 2 & 1 & 2 & 51 \\
\hline cbhll & tre44954 & cellobiohydrolase II & & & & 40 & 10 & 50 \\
\hline FRE4 & tre39576 & Ferric reductase-like transmembrane component & & 26 & & 7 & & 33 \\
\hline URA8 & trel3936 & phospholipid biosynthesis, pyrimidine base biosynthesis & & 1 & & & 32 & 33 \\
\hline cbhl & tre2242I & cellobiohydrolase I & & & & 24 & 8 & 32 \\
\hline \multirow[t]{4}{*}{ cpcl } & tre37844 & basic-leucine zipper (bZIP) transcription factor & & 21 & & 10 & & 31 \\
\hline & tre44646 & unknown & & 13 & 12 & 1 & 1 & 27 \\
\hline & tre43768 & ankyrin & & 13 & 11 & & 2 & 26 \\
\hline & tre46310 & putative exoglucanase & & I & & 8 & 15 & 24 \\
\hline ACTI & tre41819 & actin & & 8 & 2 & 8 & 5 & 23 \\
\hline \multirow[t]{3}{*}{ ITR2 } & tre43977 & intergal membrane myo-inositol transporter & I & & & 16 & 2 & 19 \\
\hline & tre45769 & aromatic compound metabolism & & 19 & & & & 19 \\
\hline & tre43393 & ADP-ribosylglycohydrolase & & 9 & 8 & & I & 18 \\
\hline prp2 & tre42899 & putative PDI-related protein & & 2 & & 3 & 13 & 18 \\
\hline MBFI & tre42770 & transcription factor MBFI & & 13 & 3 & & 1 & 17 \\
\hline HTA2 & tre35558 & histone $\mathrm{H} 2 \mathrm{~A}$ & & 9 & 4 & 1 & 2 & 16 \\
\hline $\begin{array}{l}\text { YLL023 } \\
\text { C }\end{array}$ & tre43299 & putative ER membrane protein & & 10 & 5 & & & 15 \\
\hline pdil & tre45I46 & ER-resident foldase & & 12 & & 2 & & 14 \\
\hline \multirow[t]{2}{*}{ cipl } & tre41957 & esterase homologue & & & & 6 & 8 & 14 \\
\hline & tre45203 & Transcriptional coactivator pl00 & & 4 & 7 & 2 & 1 & 14 \\
\hline hexl & tre45186 & woronin body & & 1 & & 10 & 2 & 13 \\
\hline \multirow[t]{2}{*}{ VPSI } & tre4490I & vacuolar sorting protein & & 12 & & & 1 & 13 \\
\hline & & Amount of ESTs sequenced from the individual libraries & 94 & 961 & 240 & 510 & 242 & 2047 \\
\hline
\end{tabular}

tive homologues of the corresponding ORFs were identified in the S. cerevisiae genome [20] and Swissprot [21]. Annotation of previously uncharacterised genes in T. reesei was done based on sequence similarity of the predicted ORFs of $S$. cerevisiae, since the $S$. cerevisiae genome annotation is much more advanced compared to other fungal species, and the UPR response of $S$. cerevisiae is characterised in detail. The EST sequences representing the tPA gene (98 sequences) were removed from the dataset before further analysis. Remaining 2047 sequences were submitted to EMBL with accession numbers AM111376 AM113422. As multiple short ESTs can be produced for an individual gene by the methods used, the number of ESTs does not reveal the number of ORFs present in CDNA subtraction libraries or selected by CDNA-AFLP analysis. 1850 ESTs were found to correspond to 409 predicted ORFs in the genomic sequence. In addition 97 ESTs matched outside the predicted ORFs in the $T$. reesei genome version used and two of the ESTs matched to the mitochondrial genome published earlier [22]. These 97 sequences are likely to correspond to 48 ORFs. 99 sequences did not find a match in the currently available $T$. reesei sequences. These correspond to 71 unique sequences that remained completely unidentified.

Table 2 shows the 25 most abundant ORFs in the EST collection prepared from the tPA producer and from the DTT treated culture. These include bip1 and pdi1, expected to be up regulated under secretion stress conditions in $T$. reesei $[5,7]$, and ORFs assigned to functions expected to be related to UPR in other organisms, such as ubi4, ura8, itr2, prp2 and vps1 (reviewed in $[23,24]$ ). Also transcripts expected to be very abundant, such as those encoding translation elongation factor tef1 [25], actin act1 [26], hex1 [27], cellobiohydrolases [28] and ribosomal genes [26] were represented in the libraries. These are likely to be false positives as for example northern analysis of $c b h 1$ 
and egl1 shows that they are repressed in DTT treatment and tPA producing culture (data not shown).

Some differences were detected in the content of the libraries and in the abundance of ESTs corresponding to a particular gene. ESTs of some UPR related genes (bip1, ubi4, pdi1 and vps1) were more abundant in the library derived from the DTT treated culture compared to the library from the tPA cultivation, while some genes showed an opposite trend (ura8, itr2 and erp38). Only one cellobiohydrolase EST was found in the DTT treatment library while 119 were found in the tPA cultivation library. Half of ORFs in the libraries were represented only by a single EST preventing further analysis of significant differences between the libraries. Thus, combined content of the EST libraries is presented if not otherwise stated. A list of identified ORFs is provided in the supplemental data.

$39 \%$ of the T. reesei ORFs found in the subtraction libraries or using CDNA-AFLP analysis and for which a putative function could be assigned were related to protein secretion (Table 1) which is well above the frequency of the appearance of secretion related genes in S. cerevisiae genome. The number of genes involved in transcription in the $T$. reesei EST collection was close to the relative amount of the transcription related genes that are up regulated in a UPR dependent manner in S. cerevisiae as defined by [2]. Both frequencies are lower than the frequency of transcription related genes in the S. cerevisiae genome. The more detailed dissection of the UPR up regulated genes of $S$. cerevisiae to the "coreUPR" genes and "UPR Dependent UP" in our study revealed a stronger segregation between the secretion related genes to the two groups, $63 \%$ of the "coreUPR" genes were secretion related whereas of the "UPR Dependent UP" only 31\%. Also the frequency of genes involved in transcription differed in the two groups, only $7 \%$ of the genes in the group of coreUPR were transcription related genes, whereas $26 \%$ of the "UPR Dependent UP" genes were involved in transcription.

Interestingly, a more detailed comparison of the genes represented in the T. reesei EST set and the UPR dependently up-regulated genes revealed by our data analysis or by [2] showed relatively few homologous genes in common. However, no genomic scale data exists about functional homology relationships between $T$. reesei and $S$. cerevisiae genes to enable interpretation of this.

Our analysis of genes up-regulated in T. reesei under secretion stress conditions revealed also features that clearly differ from the ones observed in S. cerevisiae. The set of $T$. reesei ESTs representing putative secretion stress related genes contained many EST corresponding to $c p c 1$, homolog of the S. cerevisiae gcn 4 , as well as three histone genes. Neither gen 4 nor histone genes were shown to be up regulated in our reanalysis of $S$. cerevisiae transcriptome data. Instead Gcn $4 p$ has been shown to be translationally induced [3]. Expression of $c p c 1$ and histone genes under secretion stress in $T$. reesei was analysed in more detail as described below.

\section{Northern analysis of a selected set of genes corresponding to the ESTs revealed by the CDNA subtraction and CDNA- AFLP analysis}

To confirm the regulation of genes revealed by the cDNA subtraction and cDNA-AFLP analyses we first selected a random set of genes corresponding to ESTs and checked induction of the genes using Northern analysis. In the set of 23 genes, twelve genes showed more than 2-fold induction after one hour treatment with DTT indicating that about half of the unique genes of the EST library derived from the DTT treated culture are actually induced (data not shown). After the random initial set of Northern analyses, we chose to analyse expression levels of genes that could reveal essential new features of $T$. reesei secretion stress. 60 novel candidates for UPR related genes, based on the functional assignments of the homologous genes in other organisms were selected for the analysis. The genes bip1 and pdi1 known to be induced under these conditions were included in the study for comparison. Deletion strains of $T$. reesei ire 1 or hac1 have not been obtained and could not be used in the analysis of UPR dependent gene expression in $T$. reesei. Therefore we defined genes showing UPR-like regulation as genes significantly induced ( $\mathrm{p}<0.016)$ after one hour treatment of the culture with DTT, as well as in culture of the tPA producing transformant and in culture of the ire 1 overexpressing strain that shows constitutive activation of the regulator HAC1 and induction of its target genes [29]. However, this does not formally exclude the possibility that the induction of a certain gene could not be caused by a nonsecretion stress specific pathway. By these criteria, 20 genes out of the set of 60 showed UPR-like regulation (Fig. 2). Nine of these genes belong to the categories previously described as UPR related ([2] or reviewed in $[23,24])$ such as genes involved in translocation, ER calcium homeostasis, folding, glycosylation, vesicle trafficking and cell wall biosynthesis. The remaining 11 genes revealed novel features in the secretion stress in T. reesei, and are described more in detail below.

\section{Nucleosomal genes are induced in secretion stress in $\mathrm{T}$. reesei}

As shown in Table 2, many ESTs corresponding to histone $\mathrm{H} 2 \mathrm{~A}$ gene are present in the secretion stress up-regulated EST collection, and based on Northern analysis, the genes for histone 2A and 4 are expressed in an UPR-like manner (Fig. 2). The H2A and H2B genes are closely linked in the T. reesei genome as are the $\mathrm{H} 3$ and $\mathrm{H} 4$ genes. The number 


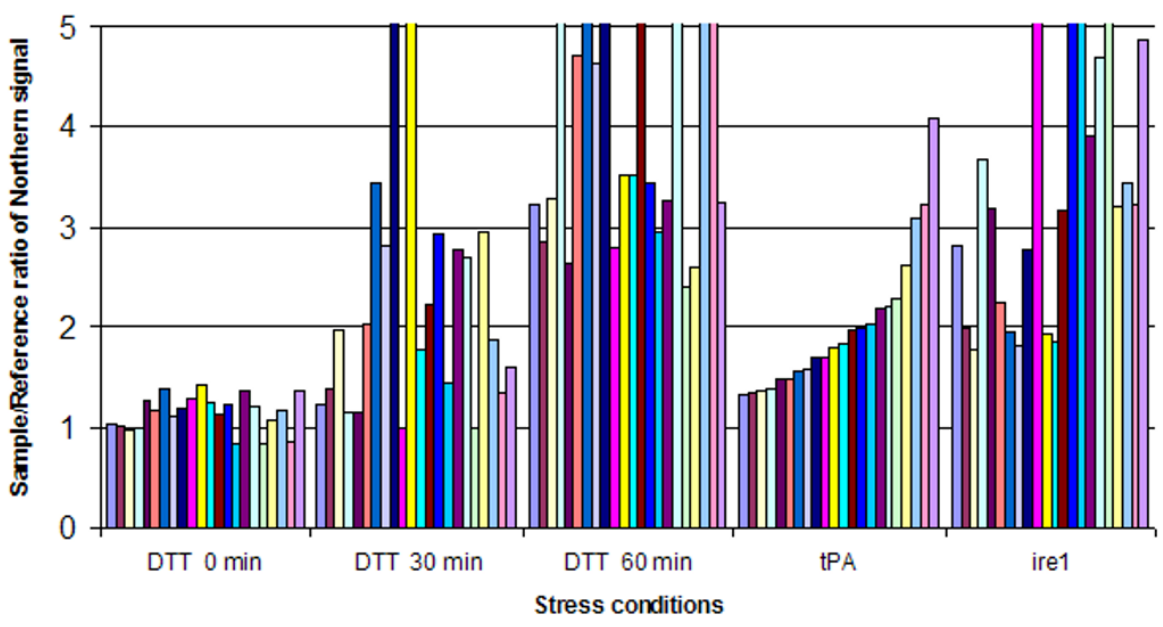

$\square$ tre 44010 - YPT2 - Traffidking 口 tre46460 - Calcium transport, ER $\square$ tre 41938 - Heterochromatin-associated 口tre 42860 - elF2beta - Translation a tre29137 - STE24 - Prenyl protease 口tre 43358 - PMR1 - Caldum transport, ER atre35558 - HTA1 - Histone H2A 口tre46135 - ARG1 - AA biosynthesis - tre 46363 - Posttranslational modification a tre18096 - HHF1 - Histone H4 口tre 45550 - GLT1 - AA biosynthesis 口tre9110 - Phospholipid transport, ER - tre 45873 - ERO1 - Folding a tre 37844 - GCN4 - AA biosynthesis 口tre43757 - ERV29 - Trafficking atre 42770 - MBF1 - AA biosynthesis $\square$ tre 42955 - BIP - Folding 口tre 44246 - SEC61 - Translocation 口tre 43342 - ARO4 - AA biosynthesis $\square$ tre 42139 - SEC53 - Glyoosylation $\square$ tre 43538 - Mic. Glut. S transferase 口tre45146 - PDI - Folding

\section{Figure 2}

Northern analysis of selected $T$. reesei genes revealed by the cDNA subtraction library and cDNA-AFLP analysis. The expression level of the genes was analysed in cultures treated with DTT for 0,30 and 60 min and in untreated reference cultures, in chemostat cultures of a tPA producing strain and its parental strain, and in a strain overexpressing ire $I$ and in its parental strain. The signals of the specific mRNAs were quantified and normalised using the signals of gpd $I$. The ratio of the signal in the analysed sample vs. the signal in a corresponding reference culture are shown for genes showing UPR-like gene expression. T. reesei protein model identifier (genome version I.2), likely S. cerevisiae homologue and function or process in which the gene is involved is indicated after gene name. DTT $0 \mathrm{~min}$, DTT treatment $0 \mathrm{~min}$; DTT 30 min, DTT treatment 30 min; DTT $60 \mathrm{~min}$, DTT treatment for $60 \mathrm{~min}$; tPA, tPA producing chemostat culture; ire l, ire l overexpressing strain.

and localisation of $T$. reesei histone ORFs resemble, but are not identical to the histone gene organisation of the filamentous fungi Aspergillus nidulans [30] and Neurospora crassa [31].

In order to elucidate whether the induction of histones in secretion stress is more widespread in filamentous fungi and not only limited to $T$. reesei, the expression level of the gene encoding the $\mathrm{H} 4$ core histone was analysed in a DTT treated culture of $A$. nidulans. The analysis showed a 2-fold induction of the gene between 30 minutes and 120 minutes of DTT treatment (Fig. 4).

\section{CPCI/GCN4 is induced in $\mathrm{T}$. reesei and A. nidulans secretion stress}

ESTs corresponding to the $T$. reesei homologue of $c p c 1$ (cross pathway control) in N. crassa (GCN4, general control nitrogen, in $S$. cerevisiae) are abundant both in the subtraction library derived from the DTT treated culture as well as in the one derived from the tPA producing culture (Table 2). Based on Northern analysis, the expression level of the gene was induced in the DTT treated culture as well as in cultures producing tPA or overexpressing ire1, thus indicating UPR-like regulation (Fig. 2).
Also the homologue for the $S$. cerevisiae MBF1 was isolated from the subtraction libraries and was among the UPR induced genes (Fig. 2). S. cerevisiae Mbf1p is a transcriptional co-activator, that has been shown to mediate Gcn4p dependent transcriptional activation by bridging the DNA binding region of Gcn4p and Spt15p (TATAbinding protein) [32]. However, MBF1 has not been described as a Gcn $4 p$ target [33-35]. The secretion stress up-regulated EST collection contained also several ESTs corresponding to putative homologues of $S$. cerevisiae SPT15 and TAF2 (TATA binding protein-Associated Factor).

To study expression of $T$. reesei $c p c 1$ target genes under secretion stress conditions, putative candidates for CPCI targets in the $T$. reesei prepublication version of the genome were identified based on sequence similarity searches against predicted S. cerevisiae Gcn4p targets [3335]. Among these we selected genes that were represented in the EST collection or that were available as cloned ESTs from [36]. Additionally we selected $\operatorname{tr} x 2, \operatorname{tr} x 1, g s r 1$ (a homologue of S. cerevisiae glr1), and gsh1 due to their role in glutathione metabolism. Northern analysis of the genes under secretion stress conditions was carried out (Fig. 3). Of the selected set of genes, glt1 (glutamate synthase), arg1 (arginosuccinate synthetase) and aro1 (pentafunc- 


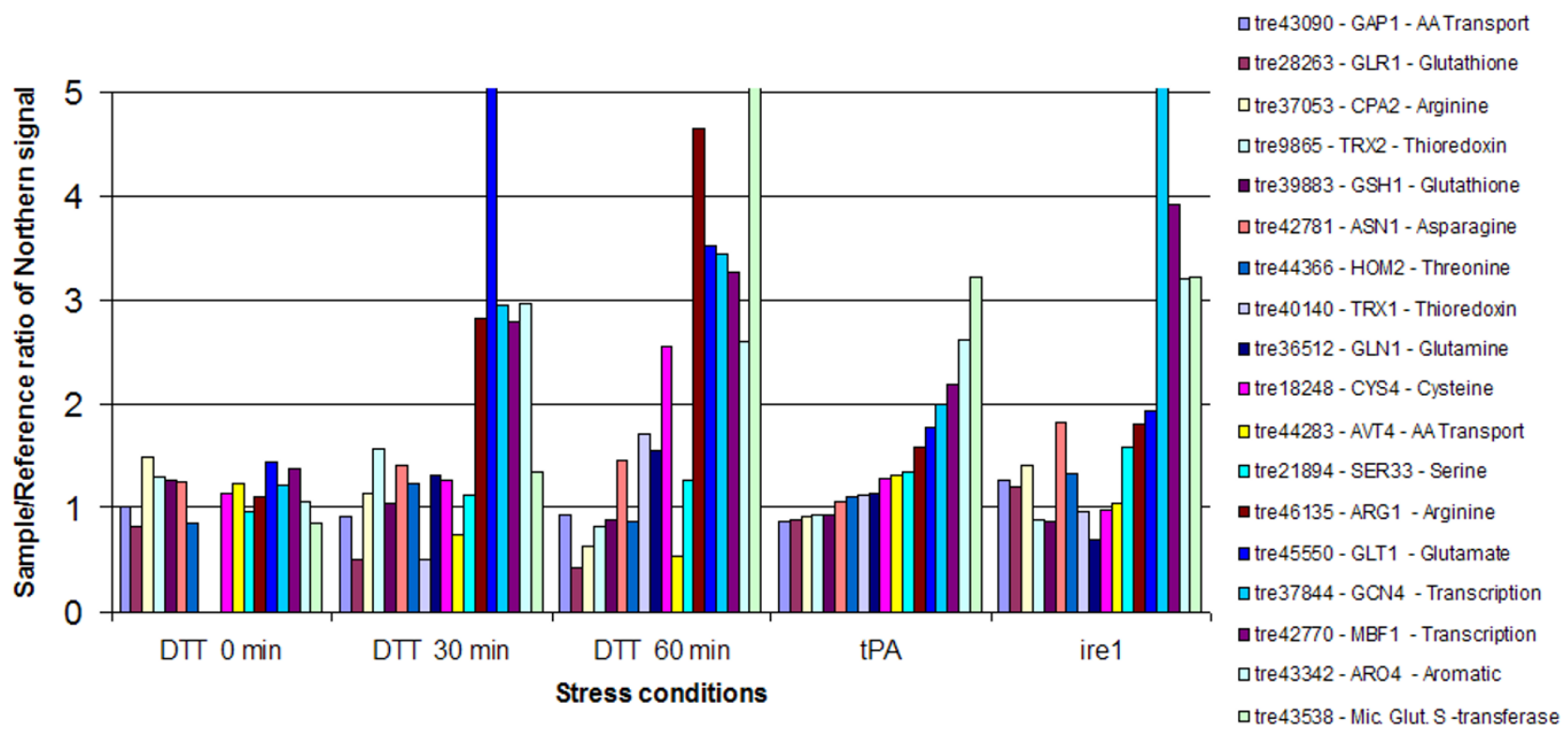

Figure 3

Northern analysis of genes related to amino acid biosynthesis and glutathione metabolism in T. reesei. The expression level of the genes was analysed in bioreactor cultures treated with DTT for 0, 30 and 60 min and in untreated reference cultures, in chemostat cultures of a tPA producing strain and its parental strain, and in a strain overexpressing ire $I$ and in its parental strain. The signals of the specific mRNAs were quantified and normalised using the signals of $g p d I$. The ratio of the signal in the analysed sample vs. the signal in a corresponding reference culture are shown. $T$. reesei protein model identifier (genome version I.2), likely S. cerevisiae homologue and amino acid for whose biosynthesis or use the gene is involved is indicated after the gene name. DTT $0 \mathrm{~min}$, DTT treatment $0 \mathrm{~min}$; DTT $30 \mathrm{~min}$, DTT treatment $30 \mathrm{~min}$; DTT $60 \mathrm{~min}$, DTT treatment for 60 min; tPA, tPA producing chemostat culture; ire l, ire l overexpressing strain, AA transport, amino acid transport.

tional arom protein, aromatic aminoacid biosynthesis) showed UPR-like regulation. Also asn1 (asparagine synthetase) was induced almost 2-fold in the ire1 overexpressing strain and cys4 (cystathionine beta-synthase) was more than 2.5-fold induced after one hour of DTT treatment, but the genes were induced to a lesser extent in the other conditions studied.

The glutathione S-transferases (GST) are a family of enzymes involved in the detoxification of oxygen radicals and other reactive intermediates (reviewed in [37]). A putative homologue of a human microsomal glutathione s-transferase 3 gene (MGST3) was found among the ESTs representing genes up-regulated under secretion stress. UPR-like regulation of the gene in T. reesei was confirmed using Northern analysis (Fig. 2).

The induction of $c p c 1$ in secretion stress was confirmed also to take place in the DTT treated culture of $A$. nidulans. The gene cpcA was induced 2-fold after 30 min treatment with DTT (Fig. 4).
Amino acid biosynthesis genes seem not to be induced in S. cerevisiae by secretion stress

In contrast to our finding in T. reesei, the GCN4 of S. cerevisiae has not been shown to be induced under secretion stress [2,3,17-19]. However, activation of Gcn4p synthesis has been reported under tunicamycin treatment in $S$. cerevisiae [3]. As secretion stress in T. reesei resulted in induction of also a set of putative target genes of the GCN4 homologue CPCI, including some amino acid biosynthesis genes, we compared the expression of the putative Gcn4p targets in the transcriptome profiling data set combined from literature.

Fig. 5 shows expression data on the amino acid biosynthesis genes that have been indicated as Gcn 4 p targets based on transcriptional profiling data on S. cerevisiae strains with constitutive GCN4 expression or GCN4 deletion [35]. These genes are clearly induced in amino acid or nitrogen depletion conditions $[17,35]$, the median gene expression value of the gene set showing 2 -fold induction. In secretion stress conditions (Fig. 5; the data sets "Treated WT", "Treated $\Delta$ ", "REF") the median $\log _{2}$ ratio of the gene 


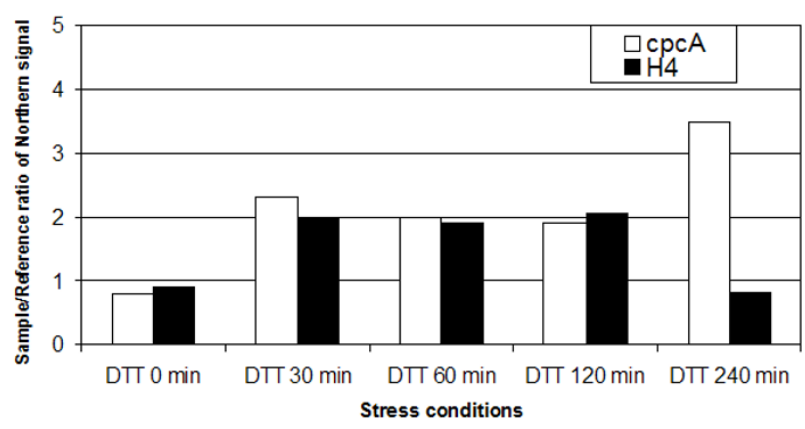

Figure 4

Northern analysis of A. nidulans cpcA and histone $\mathrm{H4}$ genes in a culture treated with DTT and in an

untreated reference culture. The expression level of the genes was analysed in a culture treated with DTT for 0,30 , 60,120 and $240 \mathrm{~min}$ and in untreated reference culture. The signals of the specific mRNAs were quantified and normalised using the signals of gpdl. The ratio of the signal in the analysed sample vs. the signal in a corresponding reference culture are shown. cpcA [70], H4 [30].

set is 0 , except in one reference experiment ("REF" data set) and in tunicamycin treatment ("Treated WT" data set), both derived from data by [18]. The Gcn4p target gene sets selected based on computational predictions $[33,34]$ show the same result in the expression profiling data although their response to amino acid depletion is less pronounced (data not shown).

\section{No clear lack of amino acids can be detected from $\mathbf{T}$. reesei cells under secretion stress}

As $c p c$ genes are known to be induced transcriptionally in response to amino acid deprivation in filamentous fungi $[38,39]$, we wanted to determine whether there was such a lack in T. reesei in our culture conditions. The concentrations of total intracellular free amino acids were determined from tPA producing strain, a DTT treated culture and culture of ire 1 over expression strain and their respective reference cultivations by HPLC. Of the 20 standard amino acids 15 were determined successfully. No systematic decrease of concentration of a single amino acid in all cultivations could be seen. Instead in DTT treated culture after $120 \mathrm{~min}$ the concentrations of alanine, arginine, and threonine were at 2.9, 3.2, 2.1, fold higher level (average of two measurements, respectively for alanine, arginine and threonine) compared to the reference culture.

\section{Discussion}

Computational reanalysis of published S. cerevisiae transcriptome profiling data allows the dissection of the effects of secretion stress

$S$. cerevisiae has served as one of the model organisms in studies on protein secretion and on factors affecting the process. The mechanisms of the unfolded protein response (UPR) activated under conditions where protein folding and transport is hampered is well characterised in $S$. cerevisiae, and transcriptional profiling data on the responses to impaired secretion process i.e. secretion stress inducing conditions, is available from various sources [2,3,17-19]. In addition there is data on responses to a large variety of other type of stress conditions. In order to create a consensus model of the responses to secretion stress in $S$. cerevisiae and to enable comparison of the corresponding responses in other organisms, we have combined the transcriptional profiling data currently available in literature. In comparison to previous studies of transcriptomic effects of secretion stress, we used a larger and more varied data set as it was combined from all the previous studies. This enables exclusion of effects specific to inducer of stress (e.g. DTT, tunicamycin or heterologous protein), the specific amount of chemical or the strain used. We also provide lists of genes upregulated or downregulated, either in UPR dependent or independent manner. This computational analysis provided a robust dissection of transcriptional effects of secretion stress in S. cerevisiae to compare our results of transcriptional effects of secretion stress in T. reesei.

Our analysis of the combined data on secretion stress in $S$. cerevisiae revealed eight specific groups of genes showing differential expression under the secretion stress conditions. Namely, the model selected a group of 46 strongly responding UPR-dependent genes ("coreUPR"), that were mainly up-regulated under the secretion stress conditions and not as a response to other type of stresses, and another group of 135 UPR-dependent up-regulated genes showing less stringent response to secretion stress (Fig. 1A and 1C). Both groups, but especially the "coreUPR" group, had a higher content of secretion related genes compared to the relative amount of secretion related genes in the genome, which is in accordance with previous information on the functional categories of UPR up-regulated genes $[2,23,24]$. [2] previously identified a set of 381 genes induced in a UPR dependent manner (Fig. 1, panel B) based on their similar behaviour to predefined model UPR genes (Fig. 1, panel B, shown in yellow) in transcriptional profiling experiment. Our test showed only 86 of these genes to be UPR dependently induced (35 were classified into "coreUPR" group, 51 in "UPR Dependent Up" group). The analysis revealed also a large number of genes that were up regulated (592 genes, "UPR Independent Up") or down regulated (603 genes, "UPR Independent Down") under secretion stress conditions, but not in a UPR dependent manner that would require functional IRE1 and HAC1 genes. 60 genes of the UPR related genes from [2] were assigned to "UPR Independent Up". The genes in these groups were responsive also to other type of 


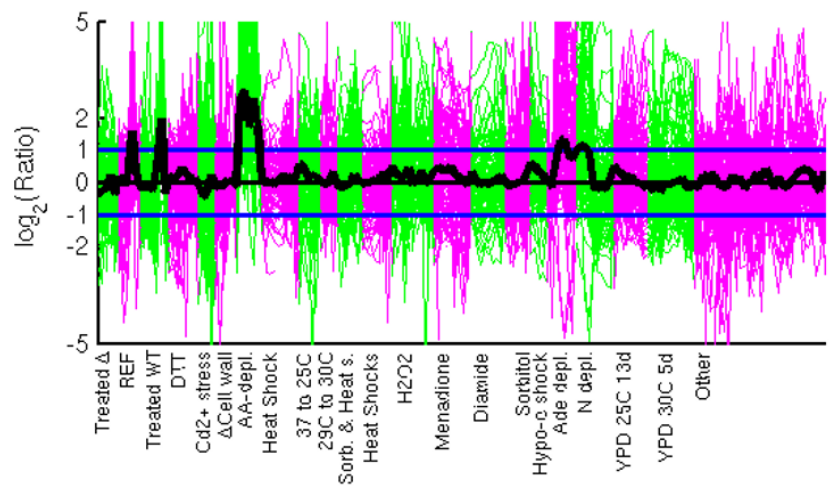

Figure 5

Expression of $S$. cerevisiae amino acid biosynthesis genes controlled by GCN4 in response to amino acid deprivation from [35] in 174 different stress experiments assembled from various articles. The expression levels are shown as $\log _{2}$ of signal ratios stressed/reference cultures in 174 different stress experiments assembled from various articles $[2,3,17,18,35,48,49]$. The expression values of individual genes as purpleand greenstriped lines, the median of gene group in black, standard deviation of the whole experiment in blue. Experiment sets are explained in Fig $\mathrm{l}$.

stress conditions (Fig. 1E and 1F), indicating that they are regulated probably through general stress pathways.

T. reesei, Aspergillus niger and Aspergillus nidulans, exhibit transcriptional down regulation of secreted proteins in secretion stress (REpression under Secretion Stress, RESS) $[7,8,40]$. It has been also shown in plant cultures (Arabidopsis thaliana) that many of the genes encoding proteins with putative signal sequences are down-regulated during treatment with DTT or tunicamycin [9]. For S. cerevisiae this has not been reported, and as shown by the trancriptome profiling studies for $S$. cerevisiae secretion stress $[2,17-19]$ and by our computational analysis (Table 1 ), only a few secreted proteins show down regulation in their transcript amounts under secretion stress in S. cerevisiae. As the transcriptomic responses of A. nidulans [40] and in A. thaliana [9] appear to affect larger amount of genes encoding secreted proteins, it is very likely that $S$. cerevisiae does not have the RESS response.

\section{Analysis of the EST collection reveals novel aspects of secretion stress in $\mathrm{T}$. reesei}

Transcriptomic responses in T. reesei secretion stress were studied under different conditions provoking secretion stress. cDNA subtraction library and cDNA-AFLP analyses were carried out from cultures producing a heterologous protein, tPA, and from cultures treated with DTT to prevent protein transport and folding. Furthermore, cultures of a strain overexpressing the UPR pathway regulator gene ire 1 were included in a further study for confirmation of induction of a selected set of genes under secretion stress using Northern analysis. The results from the combined analysis of the EST collection of different conditions confirmed the published results on the induction of previously characterised UPR related genes, such as of bip1 and pdi1 [5,7] (Table 2). Furthermore, ESTs corresponding to at least 457 genes putatively involved in secretion stress in T. reese $i$ were isolated. The EST collection contained genes from functional categories expected to be up regulated under secretion stress conditions based on transcriptomic studies in A. thaliana, A. nidulans and S. cerevisiae $[2,9,40]$ and it was clearly enriched in the number of secretion related genes as compared to the genome content of secretion related genes of $S$. cerevisiae (Table 1 ).

The responses induced by production of a heterologous protein and by the DTT treatment might also have features specific to each of these two conditions and therefore we have focused on genes under differential expression in all culture conditions. A gene was classified as a UPR-like gene if it was confirmed by Northern analysis to be up regulated after one-hour-treatment with DTT, in a tPA producing culture as well as in a strain overexpressing ire1. Northern analysis of a set of genes selected from the EST collection revealed UPR-like up regulation of a group of genes expected to be UPR up-regulated based on data obtained from other organisms, e.g. bip1, pdi1, ero1, pmr1 and sec61 or belonging to functional categories UPR upregulated in other organisms sec53, ypt2, ste24, erv29 $[2,9,40]$ (Fig. 2). Many of the genes analysed by Northern analysis were induced at a lower level in the tPA producing culture than in the DTT treated culture or in the strain overexpressing ire1 (Fig. 2). This was reflected also in the abundance of ESTs corresponding to the differentially expressed genes in the different libraries, as demonstrated by the abundantly expressed foldase/chaperon genes pdi1 and bip1 (Table 2). In addition, the analysis revealed induction of genes that have not been described as UPR induced in filamentous fungi or yeast, which are discussed more in detail below.

\section{Nucleosomal genes were induced as a response to secretion stress in $\mathrm{T}$. reesei indicating uncoupling of their regulation from cell cycle control}

The core histones are generally thought to be strictly regulated with cell cycle, active synthesis taking place during the S-phase $[41,42]$. S. cerevisiae transcriptome data collected for this study indicate that if some regulation of nucleosomal genes as a response to stress is taking place, it is primarily down regulation, and no up regulation is seen under secretion stress conditions (data not shown). On the contrary, the histone genes $\mathrm{H} 2 \mathrm{~A}$ and $\mathrm{H} 4$ were induced in $T$. reesei secretion stress in a UPR-like manner (Fig. 2). A transient induction of $\mathrm{H} 4$ histone gene was also 
observed in cultures of A nidulans subjected to DTT treatment (Fig. 4), indicating that the nucleasomal induction could be a more common phenomenon in the filamentous fungi. The induction of $\mathrm{H} 2 \mathrm{~A}$ and $\mathrm{H} 4$ appears to have no correlation with growth rate of the cells. The comparison of the expression levels of the genes in the tPA producing strain and in its parental reference strain was carried out in well controlled chemostat cultures with the same specific growth rate. Growth activation could not explain the induction either, since the treatment of the cultures with DTT retards the growth to some extent, and also the ire1 overexpression does not lead to increased growth of the fungus. Further studies are required to elucidate the significance of the increased histone gene expression under conditions where no obvious increase in DNA synthesis takes place.

\section{cPc I induction of T. reesei resembles ATF4 controlled secretion stress response in mice}

The T. reesei EST collection of genes upregulated under secretion stress contained many ESTs homologous to cpc genes of filamentous fungi or to the counterpart in S. cerevisiae, GCN4 (Table 2). UPR-like regulation of the gene in T. reesei was confirmed by Northern analysis (Fig. 2). The CPC proteins in filamentous fungi as well as the S. cerevisiae GCN4 have been shown to control amino acid biosynthesis $[38,39]$. GCN4 is thought to be involved also in responses to purine starvation, glucose limitation, growth on ethanol, high salinity, treatment with methyl methanesulfonate and treatment with rapamycin (for review see [43]). A notable difference in activation of the CPC homologues and GCN4 in response to amino acid deprivation is that $S$. cerevisiae GCN4 is mostly regulated on translational level [44] whereas the CPC-proteins in filamentous fungi are also under strong transcriptional control [38,39]. The S. cerevisiae Gcn $4 p$ and the mouse homologue ATF4 have also been shown to be involved in secretion stress $[3,12,13]$. In $S$. cerevisiae, Gcn $4 p$ is required for induction of the majority of UPR induced genes under secretion stress [2]. Mouse Atf4p appears to transcriptionally induce genes involved in glutathione biosynthesis under tunicamycin treatment. It has been suggested based on a variety of functional assays that the lack of reducing power and the need to up regulate glutathione biosynthesis were the major reasons for ATF4 induction in mouse under secretion stress conditions [13].

We carried out a Northern analysis in secretion stress conditions of a set of $T$. reesei genes whose homologues in $S$. cerevisiae have been shown to be Gcn $4 p$ targets based either on computational promoter analysis $[33,34]$ or microarray experiments [35]. As the role of CPC proteins in regulation of amino acid biosynthesis is very similar in S. cerevisiae and in filamentous fungi, it is likely that many of these selected genes are $c p c 1$ targets also in $T$. reesei. The genes glt1, arg1 and aro1 were shown to be UPR induced genes in $T$. reese $i$ based on the Northern analysis. In addition, the gene asn 1 was induced almost 2-fold in the ire 1 over-expressing strain and cys 4 was induced more than 2.5-fold after one hour DTT treatment (Fig. 2 and 3). In mice a homologue of asn1, asparagine synthase (Asns) and a homologue of $c y s 3$, cystathione $\gamma$-lyase (Cth) which follows cys4 in homocysteine and cysteine interconversion - pathway, show an ATF4 dependent regulation in secretion stress [13]. The glutathione biosynthesis gene gsh1, thioredoxin genes $(\operatorname{tr} x 1, \operatorname{tr} x 2)$ and glutathione reductase ( $g s r 1$ ) involved in glutathione related functions do not show up regulation in $T$. reese $i$, which is also the case for their homologues in mouse [13]. GLNI that synthesises glutamine from glutamate instead of glutathione neither shows any induction. At transcript level our results with $T$. reesei are in accordance with the observations in mouse in that not all the genes putatively under ATF4 regulation or involved in glutathione metabolism are affected under secretion stress conditions.

In mice, glutathione-s-transferases are activated to protect cells from oxidative stress [45] and in ER stress conditions [46]. The homologue of human microsomal glutathione s-transferase 3 (MGST3) was also among the UPR activated genes in $T$. reesei (Fig. 2). In order to determine whether induction of $c p c 1$ in $T$. reesei could be due to amino acid starvation, we determined intracellular total concentrations of 15 amino acids. No systematic lack of any of these amino acids in all conditions was detected. Based on the assembled evidence we believe that $T$. reesei is manifesting a response similar to the ATF4 dependent response of mouse.

\section{Conclusion}

We have isolated a rather large variety of genes as putative candidates for secretion stress related genes in $T$. reesei. Further analysis of the genes induced under secretion stress has revealed novel features in the stress response in T. reesei and in filamentous fungi. We have demonstrated that in addition to the previously rather well characterised induction of genes for many ER proteins or secretion related proteins also other types of responses exist. Nucleosome genes were induced both in T. reesei and in A. nidulans, this response has not previously been found from other organisms. Furthermore our results suggest that the response to secretion stress in $T$. reesei has similarities to mammalian cells in the role of $c p c 1 /$ ATF4, which has been suggested to enhance, together with a subset of its target genes, glutathione synthesis and to alleviate oxidative stress in the ER. Further studies are needed to fully uncover the role of $c p c 1$ in secretion stress in T. reesei and to elucidate whether the regulatory mechanisms of UPR involve also CPCI as a direct transcriptional factor 
involved in activation of UPR target genes in a similar manner as the Gcn4p in S. cerevisiae [3].

\section{Methods}

The transition from pre-genomic to post-genomic era in $T$. reesei research took place during the preparation of this publication. The work was planned and most laboratory experiments executed without any genomic data, but while carrying out Northern and data analysis we used $T$. reesei QM6a version 1.0/1.2 genome provided by Joint Genome Institute [47].

Comparison of S. cerevisiae transcriptome profiling data Transcriptome profiling data from S. cerevisiae at different conditions was obtained from literature [2,3,17$19,35,48,49]$. The outlier removal and normalisations provided by the authors in the original articles were used. Repeats of the same experiment were averaged and all measurements were transformed into $\log _{2}$ of the ratio of the signals under stressed conditions to those under reference conditions. Frequency distributions were visually checked and acceptable data was median centred and variance normalised. The response of an individual gene to secretion stress was defined as follows. To define IRE1 and HAC1 dependent reaction to secretion stress, values in response to production of a heterologous protein and to tunicamycin treatment [19], to 60 min DTT treatment [17], to 60 min tunicamycin and DTT treatment [2], to 30 min DTT treatment [3] and tunicamycin treatment [18] of wild type strains were used as samples (named as an experiment set "Treated WT"), and compared to the values obtained from $\triangle I R E 1 \triangle H A C 1$ deletion strain in $60 \mathrm{~min}$ tunicamycin or DTT treatments [2] and from $\triangle I R E 1$ strain in 30 min DTT treatments [3] (defined as an experiment set "Treated $\Delta$ "). To define IRE1 and HAC1 independent reaction to secretion stress the same sample values were compared to Heat Shock 000 minutes, 0 min DTT and 5 min DTT treatment [17] and two randomly picked reference experiments (ds800 vs. ds799 and ca1412 vs. ca1411 as described in [18] (named as an experiment set: reference, "REF"), where no responses apart from technical variation should be seen. Only those genes with data from all these experiments were accepted (5810 genes for dependent and 4697 for independent was taken into account). The values of each gene within the defined experiment sets ("Treated WT", "Treated $\Delta$ " and "REF") were treated as repeats of the same phenomena. The significance of the differences in the values between the experiment sets were evaluated with a Wilcoxon ranksum test [50] using a cut-off of $\mathrm{p}<0.05$, and genes showing significant difference were divided into eight gene groups. Five of them (Groups 1,3,4,5 and 6) are presented here and the rest with their selection rules are provided as supplemental data [see Additional file 1 and 2]. The rules below were used to pick groups 1 to 6 . The rules were applied in sequence of the group numbers, for example genes of group 1 would fill the requirements of group 3 and 5, but only belong to group 1 .

Group 1 ("coreUPR"), both tests (difference between "Treated WT" and "REF" and difference between "treated WT" and "Treated $\Delta$ ") significant and median treated WT $>$ median $_{\text {REF }}$ and median traated $\Delta \leq$ median $_{\text {REF; }}$;

Group 2 ("coreUPR Down"), both tests tests (difference between "Treated WT" and "REF" and difference between "treated WT" and "Treated $\Delta^{\prime \prime}$ ) significant and medi$\mathrm{an}_{\text {treated } \mathrm{WT}}<$ median $_{\mathrm{REF}}$ and median treated $\Delta \geq$ median $_{\mathrm{REF}} ;$

Group 3 ("UPR Dependent Up" regulation), significant difference between "Treated $\Delta$ " and "Treated WT" and median $_{\text {treated } \mathrm{WT}}>$ median $_{\mathrm{REF}}$ and median ${ }_{\text {treated } \Delta} \leq$ median${ }_{\mathrm{REF}}$ and not already assigned to group 1 ;

Group 4 ("UPR Dependent Down" regulation), significant difference between "Treated $\Delta$ " and "Treated WT" and median $_{\text {treated } \mathrm{WT}}<$ median $_{\mathrm{REF}}$ and median treated $\Delta \geq$ median $_{\mathrm{REF}}$ and not already assigned to group 2;

Group 5 ("UPR Independent Up" regulation), significant difference between "Treated WT" and "REF" and medi$\mathrm{an}_{\text {treated } \mathrm{WT}}>$ median $_{\mathrm{REF}}$ or both tests (difference between "Treated WT" and "REF" and difference between "Treated WT" and "Treated $\Delta "$ ") significant and median treated $_{\text {WT }}>$ median $_{\mathrm{REF}}$ and median treated $\Delta>$ median $_{\mathrm{REF}}$ and not already assigned to group 1 or 3 ;

Group 6 ("UPR Independent Down" regulation), significant difference between "Treated WT" and "REF" and median $_{\text {treated } W T}<$ median $_{\mathrm{REF}}$ or both tests (difference between "Treated WT" and "REF" and difference between "Treated WT" and "Treated $\Delta$ ") significant and medi$\mathrm{an}_{\text {treated WT }}<$ median $_{\mathrm{REF}}$ and median treated $\Delta<\operatorname{median}_{\mathrm{REF}}$ and not already assigned to group 2 or 4 ;

To describe the content of the gene groups, the amount of genes corresponding to certain functional and localisation categories from CYGD (FunCat version 2.0) [51] was counted.

\section{Strains and culture conditions}

Trichoderma reesei Rut-C30 [52] transformed with the plasmid pJMU306 to generate strain T. reesei 306/36 was kindly provided by J. Uusitalo (VTT Biotechnology). The plasmid pJMU306 contains the catalytic and linker regions of $T$. reesei cellobiohydrolase 1 (cbh1) gene fused with the coding region of human tPA gene [53]. A Kex2 cleavage site was inserted between the CBHI and tPA encoding regions and a sequence encoding (His) 6 tag was located in the $\mathrm{C}$-terminus of the construct following the 
tPA encoding region. The cbh1 promoter and terminator were used for expression of the fusion protein (J. Uusitalo, personal communication)

Pre-cultures for $T$. reesei bioreactor cultivations were carried out in $40 \mathrm{ml}$ of minimal medium containing lactose $(8 \mathrm{~g} / \mathrm{l})$ as a carbon source in $250 \mathrm{ml}$ Erlenmeyer or Nephlos flasks [54]. The medium for the shake flask cultures was also supplemented with $1.5 \mathrm{~g} / \mathrm{l}$ Stabileze QM (Methyl Vinyl Ether/Maleic Anhydride copolymer crosslinked with 1,9 Decadien, ISP Technologies, Inc.) or Junlon [55]. The flasks were inoculated with 106 spores $\mathrm{ml}^{-1}$. Cultures were incubated on a rotary shaker at $200 \mathrm{rpm}($ throw $=2.5 \mathrm{~cm})$ at $30^{\circ} \mathrm{C}$ until used as an inoculum for batch and continuous bioreactor cultures.

Cultivation for drug treatment (10 mM DTT) was carried out in an Applikon (FT Applikon Ltd., Tewkesbury, UK) bioreactor (2.3 l full working volume) on the minimal medium with $20 \mathrm{~g} / \mathrm{l}$ lactose as the carbon source. After growth to mid-exponential phase, the cultures were split in two halves, the other half was used as reference (no DTT added) and the other half was treated with $10 \mathrm{mM}$ DTT. Samples were taken regularly up to 360 minutes after drug treatment from both the reference and the treated culture.

Chemostat cultures were carried out in an Applikon (FT Applikon Ltd., Tewkesbury, UK) bioreactor (2.3 l full working volume) according to the methods of [56] using minimal medium containing $8 \mathrm{~g} / \mathrm{l}$ lactose as a carbon source. The cultures were inoculated with $200 \mathrm{ml}$ pre-culture, grown in minimal medium with $10 \mathrm{~g} / \mathrm{l}$ lactose for 3 days. The Cultures were maintained at $28^{\circ} \mathrm{C} \pm 1{ }^{\circ} \mathrm{C}$ and pH $5.5 \pm 0.1$, agitated at $900-1000$ rpm with a 3 sixbladed ( $48 \mathrm{~mm}$ diameter) Rushton turbine impeller. Aeration in the cultures was set to approx. $0.7 \mathrm{vvm}$ ( $\mathrm{l}$ air [ $1 \mathrm{cul}$ ture]-1 min-1). Foaming was controlled by continuous addition of a mixture of polypropylene glycol (PPG) of different molecular weights PPG 1025 (BDH): PPG 2025 (BDH): FoamMaster PPG (mixed molecular weight; Henkel Performance Chemicals, Leeds, UK) in the ratio 2:2:1 (35) to give a final concentration of approximately $0.01 \%$ (v/v) PPG. The dilution rate was kept constant at $0.05 \pm$ $0.005 \mathrm{~h}^{-1}$. In order to reduce the attachment of biomass to the surfaces inside the bioreactor, the impeller speed was increased to $1500 \mathrm{rpm}$ once a day for about 15 minutes, after the daily sample had been taken.

A T. reesei Rut-C30 strain overexpressing ire1 [29] and its parental strain were grown in shake flasks for 3 days in minimal medium [57] with 3\% lactose. Aspergillus nidulans FGSC A26 (biA1) was grown and treated with DTT as in [5].

\section{Analysis of growth and protein production in the bioreactor cultures}

$\mathrm{CO}_{2}$ was analysed using an ADC 7000 infrared Gas Analyzer; (The Analytical Development Co. Ltd.; U.K). Biomass from bioreactor cultures (internal and overflow spill) was determined by filtering $2 \times 10 \mathrm{ml}$ of culture, samples from the bottom and the top of the bioreactor vessel, through pre-dried and pre-weighted Whatman No. 1 filter papers. The harvested biomass was washed with at least $20 \mathrm{ml}$ of deionised water and dried to constant weight $\left[70^{\circ} \mathrm{C}\right.$ for at least 3 days or 30 minutes in a microwave at 260 watt]. Viable counts were determined as described in [58] to determine the combined fragment and conidial concentration in the culture, and also to be used as a determinant of fungal contamination.

Culture supernatant was obtained by filtration through $0.22 \mu \mathrm{m}$ MILLEX $^{\circledR}$-GP syringe filters (Millipore Corporation, Bedford, MA, USA). Aliquots of the supernatant were stored frozen at $-20^{\circ} \mathrm{C}$ for subsequent analysis. Total protein was determined by the assay of Bradford [59] using cellulase (EC 3.2.1.4) from Trichoderma reesei (Sigma C$8546)$ as the protein standard. Total cellulase activity (CBH1 and EG1) was determined essentially as decribed by [60], but using using p-nitrophenol- $\beta$-D-lactopyranosid ( $1 \mathrm{~g} / \mathrm{l}$, SIGMA N-1752) as substrate. The substrate ( $400 \mu \mathrm{l}, 1 \mathrm{mg} / \mathrm{ml}$ in $0.05 \mathrm{M}$ citric acid buffer, $\mathrm{pH} 5.0$ ) was incubated with $50 \mu \mathrm{l}$ culture supernatant (diluted as necessary) or standard (500 mg/l - $10 \mathrm{mg} / \mathrm{l})$ in an Eppendorf tube for $1 \mathrm{~h}$ at $37^{\circ} \mathrm{C}$. The reaction was stopped by adding $500 \mu \mathrm{I} \mathrm{Na}_{2} \mathrm{CO}_{3}(1 \mathrm{M})$ or Borax $(0.1 \mathrm{M})$; Borax was used when addition of $\mathrm{Na}_{2} \mathrm{CO}_{3}$ caused precipitants to form. The absorbance of the p-nitrophenol released during the reaction was measured on a spectrophotometer at a wavelength of $400 \mathrm{~nm}$. $\beta$-glucosidase and $\beta$-galactosidase activity were measured following the above protocol, but using p-nitrophenol- $\beta$-D-glucopyranosid ( $\beta$-glucosidase) and p-nitrophenol- $\beta$-D-galactopyranosid ( $\beta$-galactosidase) as substrates [61]. References to determine the absorbance contributed by the medium, were prepared by adding 500 $\mu \mathrm{l} \mathrm{Na} \mathrm{CO}_{3}(1 \mathrm{M})$ or Borax $(0.1 \mathrm{M})$ prior to addition of the sample or standard. The absorbance of the reference was subtracted from the reaction absorbance, prior to determining the enzyme concentration. Citric acid buffer (50 $\mu \mathrm{l})$ with substrate $(400 \mu \mathrm{l})$ and $500 \mu \mathrm{Na}_{2} \mathrm{CO}_{3}(1 \mathrm{M})$ or Borax $(0.1 \mathrm{M})$ was used as a blank. Total tPA was determined using an ELISA-assay (INNOGENETICS N.V. Ghent, Belgium), according to the manufacturers' instructions, except the second incubation step was carried out for 4 hours at $4^{\circ} \mathrm{C}$ instead of 1 hour at $37^{\circ} \mathrm{C}$.

\section{RNA extraction}

Total RNA was isolated using the TRIZOL reagent (GibcoBRL) as instructed by the manufacturer. For cDNA-subtraction libraries and CDNA-AFLP, poly-A fractions were 
isolated from total RNA with the Oligotex kit (Qiagen). The poly-A fraction's purity and quantity was determined by mRNA-Nano 6000 kit in the Agilent Bioanalyzer (Agilent).

\section{cDNA subtraction libraries}

We used a modified protocol of the PCR-Based Subtractive cDNA Cloning [62]. RNA was extracted from the chemostat cultures of the tPA expressing strain and its parental strain T. reesei Rut-C30 and from the DTT treated culture and the untreated reference culture of Rut-C30 after 60 minutes of DTT addition. Double stranded cDNA (dscDNA) was synthesized from RNA poly-A fractions using SuperScript Double Stranded Synthesis Kit (Life Technologies). The dscDNA was digested with AluI and Rsa I enzymes (New England Biolabs). Adaptors for fragmented cDNA were annealed from following oligos (Sigma) and ligated to cDNA: for the stressed conditions (either the tPA producing culture or the DTT treated culture) A: 5'-GAGTATCAAGGATCCAAGCAT-3' and B: 5'ATGCTTGGATCCTTGATACTCTTCA-3' and for the reference conditions (either the chemostat culture of the parental strain or the untreated Rut-C30 batch bioreactor culture) C: 5'-CTACATGCGTCTTAAGTTGAT-3' and D: 5'GAGTACCAAGATATCCAGCAT-3'. The adaptor ligated cDNA was purified using Qiaquick Gel Extraction Kit (Qiagen). PCR was done from the purified cDNA with the adaptor oligos $\mathrm{A}$ or $\mathrm{C}$ for their respective fragment pools. Dynazyme EXT (Finnzymes) polymerase was used in all PCR reactions and PCR was carried out for 18 cycles with an annealing temperature of $54^{\circ} \mathrm{C}$. Instead of biotinylated nucleotides, $5^{\prime}$ biotinylated primers were used for preparing substracting cDNA. The PCR products were purified with Qiaquick Gel Extraction Kit (Qiagen). The PCR products from the stressed cultures were hybridised with the products from the corresponding reference cultures. Hybridisations were carried with $10 \mu \mathrm{g}$ of the substracting cDNA and approximately $1 \mu \mathrm{g}$ of the cDNA pool from which the unique cDNAs were to be isolated. Biotin labelled hybrids were removed with Dynabeads (Dynal) according to manufacturer's instructions. Repeated cycles of hybridisation were carried out and the progress of subtraction was monitored by scintillation counting of the hybridisation products, agarose gel analysis of PCR products and dotblots hybridised with relevant probes.

The subtracted cDNA fragment pools representing genes up-regulated in stressed conditions were digested with BamHI (the site located in the A/B adaptor) and cloned to pBK-MCV phagemid vector in XL1-Blue MRF' strain with ZAP Express Predigested Gigapack Cloning Kits (Stratagen). Colonies of XL1-Blue MRF' were picked with the automated colony picker QPix (Genetix). Plasmids were purified with Plasmid miniprep96 kit (Millipore) and sequenced with T7 and/or T3 primers with BigDye 1.1 kit in an ABIprism 9600 sequencer (Applied Biosystems) according to manufacturer's instructions.

\section{CDNA-AFLP}

CDNA-AFLP experiments were carried out as described previously [63]. RNA was extracted from cultivation of the tPA expressing strain in a chemostat and the DTT treated cultivation after 60 minutes of DTT addition and their respective references. In short dscDNA was made from reference and stressed RNAs and respective pools of unique gene specific 3' fragments were made, amplified by PCR and fractionated using electrophoresis.

To generate the fragments, dscDNA were digested first with BstYI and then with MseI. For preamplification, BstYI end primers having a $\mathrm{C}$ in 3 ' end were used. A selection of three nucleotides was used, BstYI end with two selective nucleotides and MseI end with one selective nucleotide. Bands were scored visually and those that showed very clear up regulation in both stressed samples were cut out and sequenced.

\section{Northern analysis}

Northern analysis was carried out using standard protocols [64]. ESTs from the cDNA subtraction library clones were PCR amplified using T7 and T3 primers, and the fragments were digested with BamHI to remove extra sequence and used as probes in the Northern analyses. Probes specific for the genes $g \ln 1$ (CB896216.1), cys4 (CB895493.1), ans1 (CB904095.1), glt1 (CB898755.1), aro4 (CB903024.1), hom2 (CB902136.1) and ser33, (CB899553.1) were obtained by PCR amplification of clones from EST library [36] using the respective sequencing primers. Gene specific probe fragments from genomic DNA were PCR amplified using the following primers: A. nidulans $\mathrm{H} 4$ gene, gcgagagatgttgagaatgga and gtgaagcagttgggagacg; $c p c A$ gtccacctgtcccgctc and atgtctccctgtcgctcaag; $T$. reesei microsomal glutathione-S transferase, tcccttcgtctctaccaacaam and ttgaggttcatttccatttcg; gsr1, taagacggagggtgtggaag and, gccgcaggaaggtgttgt; trx2, tgccgaagagttcaaaaagg and cagctcgtccacgtcaaa; gsh1, ttcactcaccccttttaccc and atgttttcgtccaccttctt; trx1, actggcaccatccaccac and gcctcctcgaccetcttct. All PCR amplified products were subsequently analysed on agarose gels, and purified using Qiaquick Gel Extraction Kit (Qiagen).

$5 \mu \mathrm{g}$ of total RNA isolated from the chemostat cultures of the tPA producing transformant and its parental strain and from the DTT treated culture and the corresponding untreated culture at different time points, as well as RNA isolated from the shake flask cultures of ire 1 overproducing strain and its parental strain were subjected to the analysis. The Northern signals were quantified using a phosphoimager (Typhoon 8600, AmershamBiosciences). The $\log _{2}$ of the ratio of the signal in the stressed culture 
and in the reference culture were determined. The $\log _{2}$ ratio from DTT treatment after one hour (DTT treated culture vs. the untreated culture at the same time point), tPA producing transformant (tPA producer vs. the parental strain) and ire 1 overproducing transformant (ire 1 overproducer vs. its parental strain at the same time point) were treated as repeats and the significance of the values was tested against all $\log _{2}$ ratios in the DTT treated cultures just before addition of DTT. The significance of the quantified signals was evaluated by a Wilcoxon ranksum test [50] with a cutoff of $\mathrm{p}<0,016$ (lowest available $\mathrm{p}$-value with this sample size).

\section{Sequence analysis}

Basecalling was done with Phred [65]. Removal of low quality sequences, quality trimming, primer removal and removal of host genome sequences was done with the program Staden [66]. Smith-Waterman sequence similarity searches were carried out with Genematcher2 (Paracel) at Finnish IT centre for science. The sequences were matched to their corresponding predicted open reading frames in T. reesei genome [47] with a cut-off of $96 \%$ identity. Sequences not giving a reasonable match in $T$. reesei genome were matched against Neurospora crassa genome [67] and Swissprot [21]. Because the T. reesei annotation was incomplete the genes were placed in functional categories based on their S. cerevisiae [20] and Swissprot [21] sequence homologies. A cut-off of $\mathrm{E}<1 \times 10^{-20}$ and a fixed database size of $9 \times 10^{9}$ (which was the approximate size off EMBL at the time the work was started) was used. Results of genomic matches were manually checked against the Swissprot [21] matches to make sure that none contradicted. tPA derived ESTs were removed based on sequence similarity prior to database searches. The homologies of the ESTs are provided in supplemental data [see Additional file 3]. In addition the amount of ESTs corresponding to certain functional and localisation categories from CYGD (FunCat version 2.0) [51] was counted.

\section{Determination of concentration of intracellular amino acids by HPLC}

The amino acid concentrations were determined as in [68]. The method is based on Waters AccQ.Tag Chemistry (Waters Corp., Milford. MA. Usa). The sample was lyophilized and finely ground in mortar. $10 \mathrm{mg}$ of ground sample was extracted for $2 \mathrm{~h}$ with $1 \mathrm{ml}$ of $20 \mathrm{mM} \mathrm{HCl}$. Samples were then derivatized as such, diluted $1+1$ with $20 \mathrm{mM} \mathrm{HCl}$ and diluted $1+1$ with $0.032 \mathrm{mM}$ amino acid standard solution in $20 \mathrm{mM} \mathrm{HCl}$. The derivatization was carried out according to Waters AccQ.Tag manual.

The chromatography instrument consisted of Alliance 2690 Separation module and M-474 fluorescence detector monitoring at $\lambda_{\text {ex. }}=248 \mathrm{~nm} / \lambda_{\text {em. }}=395 \mathrm{~nm}$. The system was controlled and data treated with Empower chromatography software. All the instruments and derivatization reagent were from Waters corp. (Milford, MA. USA). For separations Carbamate analysis column was used. The eluent consisted of $140 \mathrm{mM}$ sodium acetate $+17 \mathrm{mM}$ trietylamine $\mathrm{pH} 4.95$ (solvent $\mathrm{A}$ ) and $60 \%(\mathrm{w} / \mathrm{w})$ acetonitrile:water (solvent B). The flow-rate was $1.5 \mathrm{ml} / \mathrm{min}$ and the column temperature was $37^{\circ} \mathrm{C}$. The gradient was $0-2 \% \mathrm{~B}$ in $0.5 \mathrm{~min} ; 2-7 \% \mathrm{~B}$ in 16.6 minutes; $7-13 \% \mathrm{~B}$ in 6 minutes; $13-34 \%$ B in 14 minutes, $34-34 \%$ B for 5 minutes with final washing step of $100 \%$ B for 2 minutes. All gradients were linear. Injection volume was $10 \mu \mathrm{L}$.

\section{Authors' contributions}

MA carried out cDNA-subtraction library, cDNA-AFLP and Northern analysis and all data analysis and drafted the manuscript. TP participated in the design and coordination of the study and in drafting of the manuscript. KL carried out bioreactor cultivations and growth and protein production analysis from them and helped to draft the manuscript. MS participated in the design and coordination of the study and helped to draft the manuscript. MV participated in the design of the study and carried out cultivations and molecular genetics related to the ire 1 overexpressing strain. TS carried our HPLC analysis of amino acids and helped to draft the manuscript. GR participated in conceiving of the study, in its design and in its coordination. MP conceived of the study, and participated in its design and coordination and helped to draft the manuscript.

\section{Additional material}

\section{Additional File 1}

A tab limited text file including: 1. List of experiment titles in S. cerevisiae gene expression plots. 2. Rules to divide ORFs having significant $p$ values into groups. 3. Systematic names of ORFs in the groups Click here for file

[http://www.biomedcentral.com/content/supplementary/14712164-7-32-S1.txt]

\section{Additional File 2}

Plot of the gene expression values of the three gene groups not discussed in the article.

Click here for file

[http://www.biomedcentral.com/content/supplementary/14712164-7-32-S2.png]

\section{Additional File 3}

A tab limited text file including: 1. Mapping of ESTs to T. reesei genome and homologues in $\mathrm{S}$. cerevisiae or other species

Click here for file

[http://www.biomedcentral.com/content/supplementary/1471-

2164-7-32-S3.txt] 


\section{Acknowledgements}

We thank Aili Grundstöm for excellent technical assistance and Matej Oresic and Teemu Kivioja for very useful discussions on data-analysis, Alan Goossens and Dirk Inzé (University of Ghent, Belgium) for a wonderful change to learn cDNA-AFLP and Tom Mitchell (North Carolina State University, USA) for providing clones from [36]. This work was supported by the European Union V Framework Program Eurofung QLK3-CT-199900729, and the research program Life 2000 (Academy of Finland and National Technology Agency of Finland, 2000-2003, Project no. 50023). This work was also part of the research programme "VTT Industrial Biotechnology" (Academy of Finland; Finnish Centre of Excellence programme $2000-2005$, project no. 64330).

\section{References}

I. Cox JS, Walter P: A novel mechanism for regulating activity of a transcription factor that controls the unfolded protein response. Cell 1996, 87:391-404.

2. Travers KJ, Patil CK, Wodicka L, Lockhart DJ, Weissman JS, Walter PURBWSNSS: Functional and Genomic Analyses Reveal an Essential Coordination between the Unfolded Protein Response and ER-Associated Degradation. Cell 2000, I 0 I:249-258.

3. Patil CK, Li H, Walter P: Gcn4p and novel upstream activating sequences regulate targets of the unfolded protein response. PLoS Biol 2004, 2:E246.

4. Valkonen M, Penttila M, Saloheimo M: Effects of inactivation and constitutive expression of the unfolded- protein response pathway on protein production in the yeast Saccharomyces cerevisiae. Appl Environ Microbiol 2003, 69:2065-2072.

5. Saloheimo M, Valkonen M, Penttila M: Activation mechanisms of the HACI-mediated unfolded protein response in filamentous fungi. Mol Microbiol 2003, 47: I |49-I I6I I.

6. Mulder HJ, Saloheimo M, Penttila M, Madrid SM: The transcription factor HACA mediates the unfolded protein response in Aspergillus niger, and up-regulates its own transcription. $\mathrm{Mol}$ Genet Genomics 2004, 27 I: I30-140.

7. Pakula TM, Laxell M, Huuskonen A, Uusitalo J, Saloheimo M, Penttila $M$ : The effects of drugs inhibiting protein secretion in the filamentous fungus Trichoderma reesei. Evidence for downregulation of genes that encode secreted proteins in the stressed cells. J Biol Chem 2003, 278:450 I I-45020.

8. Al-Sheikh H, Watson AJ, Lacey GA, Punt PJ, MacKenzie DA, Jeenes DJ, Pakula T, Penttila M, Alcocer MJ, Archer DB: Endoplasmic reticulum stress leads to the selective transcriptional downregulation of the glucoamylase gene in Aspergillus niger. Mol Microbiol 2004, 53: I73।-1742.

9. Martinez IM, Chrispeels MJ: Genomic analysis of the unfolded protein response in Arabidopsis shows its connection to important cellular processes. Plant Cell 2003, I 5:56 I-576.

10. Lee K, Tirasophon W, Shen X, Michalak M, Prywes R, Okada T, Yoshida $H$, Mori $K$, Kaufman RJ: IREI-mediated unconventional mRNA splicing and S2P-mediated ATF6 cleavage merge to regulate $X B P I$ in signaling the unfolded protein response. Genes Dev 2002, I 6:452-466.

II. Harding HP, Zhang Y, Ron D: Protein translation and folding are coupled by an endoplasmic-reticulum-resident kinase. Nature 1999, 397:271-274.

12. Harding HP, Zhang Y, Bertolotti A, Zeng H, Ron D: Perk is essential for translational regulation and cell survival during the unfolded protein response. Mol Cell 2000, 5:897-904.

13. Harding HP, Zhang Y, Zeng H, Novoa I, Lu PD, Calfon M, Sadri N, Yun C, Popko B, Paules R: An Integrated Stress Response Regulates Amino Acid Metabolism and Resistance to Oxidative Stress. Molecular Cell 2003, I I:619-633.

14. Averous J, Bruhat A, Jousse C, Carraro V, Thiel G, Fafournoux P: Induction of CHOP expression by amino acid limitation requires both ATF4 expression and ATF2 phosphorylation. J Biol Chem 2004, 279:5288-5297.

15. Saloheimo M, Lund M, Penttila ME: The protein disulphide isomerase gene of the fungus Trichoderma reesei is induced by endoplasmic reticulum stress and regulated by the carbon source. Mol Gen Genet 1999, 262:35-45.
16. Collen A, Saloheimo M, Bailey M, Penttila M, Pakula TM: Protein production and induction of the unfolded protein response in Trichoderma reesei strain Rut-C30 and its transformant expressing endoglucanase I with a hydrophobic tag. Biotechnol Bioeng 2005, 89:335-344.

17. Gasch AP, Spellman PT, Kao CM, Carmel-Harel O, Eisen MB, Storz $G$, Botstein D, Brown PO: Genomic expression programs in the response of yeast cells to environmental changes. Mol Biol Cell 2000, I I:424I-4257.

18. Hughes TR, Marton MJ, Jones AR, Roberts CJ, Stoughton R, Armour CD, Bennett HA, Coffey E, Dai H, He YD, Kidd MJ, King AM, Meyer MR, Slade D, Lum PY, Stepaniants SB, Shoemaker DD, Gachotte D, Chakraburtty K, Simon J, Bard M, Friend SH: Functional discovery via a compendium of expression profiles. Cell 2000, 102:109-126.

19. Casagrande R, Stern P, Diehn M, Shamu C, Osario M, Zuniga M, Brown PO, Ploegh H: Degradation of Proteins from the ER of S. Cerevisiae Requires an Intact Unfolded Protein Response Pathway. Molecular Cell 2000, 5:729-735.

20. Dolinski K: Saccharomyces Genome Database. "Saccharomyces Genome Database" [http://www.yeastgenome.org/].

21. Boeckmann B, Bairoch A, Apweiler R, Blatter MC, Estreicher A, Gasteiger E, Martin MJ, Michoud K, O'Donovan C, Phan I, Pilbout S, Schneider M: The SWISS-PROT protein knowledgebase and its supplement TrEMBL in 2003. Nucleic Acids Res 2003, 3 I:365-370.

22. Chambergo FS, Bonaccorsi ED, Ferreira AJ, Ramos AS, Ferreira Junior JR, Abrahao-Neto J, Farah JP, El-Dorry H: Elucidation of the metabolic fate of glucose in the filamentous fungus Trichoderma reesei using expressed sequence tag (EST) analysis and cDNA microarrays. J Biol Chem 2002, 277:13983-I3988.

23. Patil C, Walter P: Intracellular signaling from the endoplasmic reticulum to the nucleus: the unfolded protein response in yeast and mammals. Current Opinion in Cell Biology 2001, I 3:349-355.

24. Kaufman RJ: Orchestrating the unfolded protein response in health and disease. J Clin Invest 2002, I I 0: I389- I 398.

25. Nakari T, Alatalo E, Penttila ME: Isolation of Trichoderma reesei genes highly expressed on glucose-containing media: characterization of the tefl gene encoding translation elongation factor I alpha. Gene 1993, 136:313-318.

26. Velculescu VE, Zhang L, Zhou W, Vogelstein J, Basrai MA, Bassett DEJ, Hieter P, Vogelstein B, Kinzler KW: Characterization of the yeast transcriptome. Cell 1997, 88:243-25I.

27. Bergquist PL, Te'o VS, Gibbs MD, Curach NC, Nevalainen KM: Recombinant enzymes from thermophilic micro-organisms expressed in fungal hosts. Biochem Soc Trans 2004, 32:293-297.

28. Penttila IM, Limon C: Molecular Biology of Trichoderma and Biotechnological Applications. In Handbook of Fungal Biotechnology 2 nd edition. Edited by: Arora DK. New York, Marcel Dekker, Inc.; 2004:413-427.

29. Valkonen M, Penttila M, Saloheimo $M$ : The ire I and ptc2 genes involved in the unfolded protein response pathway in the filamentous fungus Trichoderma reesei. Mol Genet Genomics 2004, 272:443-45I.

30. Ehinger A, Denison SH, May GS: Sequence, organization and expression of the core histone genes of Aspergillus nidulans. Mol Gen Genet 1990, 222:416-424.

31. Hays SM, Swanson J, Selker EU: Identification and characterization of the genes encoding the core histones and histone variants of Neurospora crassa. Genetics 2002, 160:961-973.

32. Takemaru K, Harashima S, Ueda H, Hirose S: Yeast coactivator MBF I mediates GCN4-dependent transcriptional activation. Mol Cell Biol 1998, I 8:4971-4976.

33. Kellis M, Patterson N, Endrizzi M, Birren B, Lander ES: Sequencing and comparison of yeast species to identify genes and regulatory elements. Nature 2003, 423:24I-254.

34. Fondrat C, Kalogeropoulos A: Approaching the function of new genes by detection of their potential upstream activation sequences in Saccharomyces cerevisiae: application to chromosome III. Curr Genet I994, 25:396-406.

35. Natarajan K, Meyer MR, Jackson BM, Slade D, Roberts C, Hinnebusch AG, Marton MJ: Transcriptional profiling shows that Gcn4p is a master regulator of gene expression during amino acid starvation in yeast. Mol Cell Biol 2001, 21 : 4347-4368. 
36. Foreman PK, Brown D, Dankmeyer L, Dean R, Diener S, Dunn-Coleman NS, Goedegebuur F, Houfek TD, England GJ, Kelley AS, Meerman HJ, Mitchell T, Mitchinson C, Olivares HA, Teunissen PJ, Yao J, Ward $M$ : Transcriptional regulation of biomass-degrading enzymes in the filamentous fungus Trichoderma reesei. $\mathrm{J} \mathrm{Biol}$ Chem 2003, 278:31988-31997.

37. Hayes JD, McLellan LI: Glutathione and glutathione-dependent enzymes represent a co-ordinately regulated defence against oxidative stress. Free Radic Res 1999, 3 I:273-300.

38. Wanke C, Eckert S, Albrecht G, van Hartingsveldt W, Punt PJ, van den Hondel CA, Braus GH: The Aspergillus niger GCN4 homologue, cpcA, is transcriptionally regulated and encodes an unusual leucine zipper. Mol Microbiol 1997, 23:23-33.

39. Paluh JL, Orbach MJ, Legerton TL, Yanofsky C: The cross-pathway control gene of Neurospora crassa, cpc-I, encodes a protein similar to GCN4 of yeast and the DNA-binding domain of the oncogene v-jun-encoded protein. Proc Natl Acad Sci U S A 1988, 85:3728-3732.

40. Sims AH, Gent ME, Lanthaler K, Dunn-Coleman NS, Oliver SG, Robson GD: Transcriptome analysis of recombinant protein secretion by Aspergillus nidulans and the unfolded-protein response in vivo. Appl Environ Microbiol 2005, 71:2737-2747.

4I. Meshi T, Taoka KI, Iwabuchi M: Regulation of histone gene expression during the cell cycle. Plant Mol Biol 2000, 43:643-657.

42. Marzluff WF, Duronio RJ: Histone mRNA expression: multiple levels of cell cycle regulation and important developmental consequences. Curr Opin Cell Biol 2002, 14:692-699.

43. Hinnebusch AG, Natarajan K: Gcn4p, a master regulator of gene expression, is controlled at multiple levels by diverse signals of starvation and stress. Eukaryot Cell 2002, I:22-32.

44. Albrecht G, Mosch HU, Hoffmann B, Reusser U, Braus GH: Monitoring the Gcn 4 protein-mediated response in the yeast Saccharomyces cerevisiae. J Biol Chem 1998, 273:I2696-I 2702.

45. Chanas SA, liang $\mathrm{Q}$, McMahon M, McWalter GK, McLellan LI, Elcombe CR, Henderson CJ, Wolf CR, Moffat GJ, Itoh K, Yamamoto $M$, Hayes JD: Loss of the Nrf2 transcription factor causes a marked reduction in constitutive and inducible expression of the glutathione S-transferase Gsta I, Gsta2, Gstm I, Gstm2, Gstm 3 and Gstm4 genes in the livers of male and female mice. Biochem / 2002, 365:405-4I6.

46. Gilmore WJ, Kirby GM: Endoplasmic reticulum stress due to altered cellular redox status positively regulates murine hepatic CYP2A5 expression. J Pharmacol Exp Ther 2004, 308:600-608.

47. JGI Trichoderma reesei draft genome [http://gsphere.lanl.gov/ trirel/trirel.home.html]

48. Fauchon M, Lagniel G, Aude JC, Lombardia L, Soularue P, Petat C, Marguerie G, Sentenac A, Werner M, Labarre J: Sulfur sparing in the yeast proteome in response to sulfur demand. Mol Cell 2002, 9:713-723.

49. Lagorce A, Hauser NC, Labourdette D, Rodriguez C, Martin-Yken H, Arroyo J, Hoheisel JD, Francois J: Genome-wide analysis of the response to cell wall mutations in the yeast Saccharomyces cerevisiae. J Biol Chem 2003, 278:20345-20357.

50. Gibbons JD, Chakraborti S: Nonparametric Statistical Inference. 3rd edition. London, UK, Marcel Dekker; 1992:572.

5I. Mewes HW, Amid C, Arnold R, Frishman D, Guldener U, Mannhaupt G, Munsterkotter M, Pagel P, Strack N, Stumpflen V, Warfsmann J, Ruepp A: MIPS: analysis and annotation of proteins from whole genomes. Nucleic Acids Res 2004, 32 Database issue:D4I-4.

52. Montenecourt BS, Eveleigh DE: Selective screening methods for the isolation of high yielding cellulase mutants of Trichoderma reesei. Advances in Chemistry Series 1979, I 81:289-301.

53. Pennica D, Holmes WE, Kohr WJ, Harkins RN, Vehar GA, Ward CA Bennett WF, Yelverton E, Seeburg PH, Heyneker HL, Goeddel DV Collen D: Cloning and expression of human tissue-type plasminogen activator cDNA in E. coli. Nature 1983, 301:214-221.

54. Trinci APJ: Culture turbidity as a parameter of mould growth. Transactions of the British Mycological Society 1972, 58:467-473.

55. Jones P, Moore D, Trinci APJ: Effects of Junlon and Hostacerin on the electrokinetic properties of spores of Aspergillus niger, Phanerochaete chrysosporium and Geotrichum candidum. Journal of General Microbiology 1988, I 34:235-240.
56. Wiebe MG, Trinci APJ: Dilution rate as a determinant of mycelial morpohology in continous culture. Biotechnology and Bioengineering |99|, 38:75-8|.

57. Penttila M, Nevalainen $H$, Ratto $M$, Salminen E, Knowles ]: A versatile transformation system for the cellulolytic filamentous fungus Trichoderma reesei. Gene 1987, 6 I: I55-164.

58. Wiebe MG, Trinci APJ, Cunliffe B, Robson GD, Oliver SG: Appearence of morphological (colonial) mutants in glucoselimited continous flow cultures of Fusarium graminearum. Mycological Research 199|, 95:|284- | 288.

59. Bradford MM: A rapid and sensitive method for the quantitation of microgram quantities of protein utilizing the principle of protein-dye binding. Anal Biochem 1976, 72:248-254.

60. van Tilbeurgh $\mathrm{H}$, Claeyssens $M$ : The use of 4-methylumbelliferyl and other chromophoric glycosides in the study of cellulolytic enzymes. FEBS Letters 1982, I49:152-I56.

61. Kubicek CP: Release of carboxymethyl-cellulase and beta-glucosidase from cell walls of Trichoderm reesei. European Journal of Applied Microbiology and Biotechnology 1981, I3:226-23I.

62. Ausubel FM, Brent R, Kingston RE, Moore DD, Seidman JG, Smith JA Struhl K: Current protocols in Molecular Biology. Edited by: Ausubel FM, Brent R, Kingston, RE, Moore DD, Seidman JG, Smith JA and Struhl K. , John Wiley \& Sons, Inc.; 1994.

63. Breyne P, Dreesen R, Cannoot B, Rombaut D, Vandepoele K, Rombauts S, Vanderhaeghen R, Inze D, Zabeau M: Quantitative cDNAAFLP analysis for genome-wide expression studies. Mol Genet Genomics 2003, 269: I73-I79.

64. Sambrook J, Russell DW: Molecular Cloning - a laboratory manual. New York, USA, Cold Spring Harbor Press; $200 \mathrm{I}$

65. Ewing B, Hillier L, Wendl MC, Green P: Base-calling of automated sequencer traces using phred. I. Accuracy assessment. Genome Res 1998, 8:175-185.

66. Staden R: The Staden sequence analysis package. Mol Biotechnol 1996, 5:233-24I.

67. Galagan JE, Calvo SE, Borkovich KA, Selker EU, Read ND, Jaffe D, FitzHugh W, Ma LJ, Smirnov S, Purcell S, Rehman B, Elkins T, Engels R, Wang S, Nielsen CB, Butler J, Endrizzi M, Qui D, lanakiev P, Bell-Pedersen D, Nelson MA, Werner-Washburne M, Selitrennikoff CP, Kinsey JA, Braun EL, Zelter A, Schulte U, Kothe GO, Jedd G, Mewes W, Staben C, Marcotte E, Greenberg D, Roy A, Foley K, Naylor J, StangeThomann N, Barrett R, Gnerre S, Kamal M, Kamvysselis M, Mauceli E, Bielke C, Rudd S, Frishman D, Krystofova S, Rasmussen C, Metzenberg RL, Perkins DD, Kroken S, Cogoni C, Macino G, Catcheside D, Li W, Pratt RJ, Osmani SA, DeSouza CP, Glass L, Orbach MJ, Berglund IA, Voelker R, Yarden O, Plamann M, Seiler S, Dunlap J, Radford A, Aramayo R, Natvig DO, Alex LA, Mannhaupt G, Ebbole DJ, Freitag M, Paulsen I, Sachs MS, Lander ES, Nusbaum C, Birren B: The genome sequence of the filamentous fungus Neurospora crassa. Nature 2003, 422:859-868.

68. Cohen SA, Michaud DP: Synthesis of a fluorescent derivatizing reagent, 6-aminoquinolyl-N-hydroxysuccinimidyl carbamate, and its application for the analysis of hydrolysate amino acids via high-performance liquid chromatography. Anal Biochem 1993, 21 I:279-287.

69. Brem RB, Yvert G, Clinton R, Kruglyak L: Genetic dissection of transcriptional regulation in budding yeast. Science 2002 , 296:752-755

70. Hoffmann B, Valerius $O$, Andermann M, Braus GH: Transcriptional autoregulation and inhibition of mRNA translation of amino acid regulator gene cpcA of filamentous fungus Aspergillus nidulans. Mol Biol Cell 200 I, I 2:2846-2857. 